$1-1-1916$

\title{
The Apple as Affected by Varying Degrees of Dormant and Seasonal Pruning
}

W.H. Alderman

E. C. Auchter

Follow this and additional works at: https://researchrepository.wvu.edu/ wv_agricultural_and_forestry_experiment_station_bulletins

\section{Digital Commons Citation}

Alderman, W. H. and Auchter, E. C., "The Apple as Affected by Varying Degrees of Dormant and Seasonal Pruning" (1916). West Virginia Agricultural and Forestry Experiment Station Bulletins. 158.

https://researchrepository.wvu.edu/wv_agricultural_and_forestry_experiment_station_bulletins/158 @ WVU. It has been accepted for inclusion in West Virginia Agricultural and Forestry Experiment Station Bulletins by an authorized administrator of The Research Repository @ WVU. For more information, please contact ian.harmon@mail.wvu.edu. 
West Virginia University Libraries

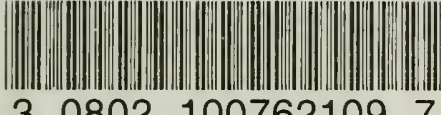

308021007621097 



\section{2yest Virginía finibersity Aqricultural Experiment Station MORGANTOWN}

DEPARTMENT OF HORTICULTURE

\section{The Apple as Affected by Varying Degrees of Dormant and Seasonal Pruning}

\section{TECHNICAL BULLETIN}

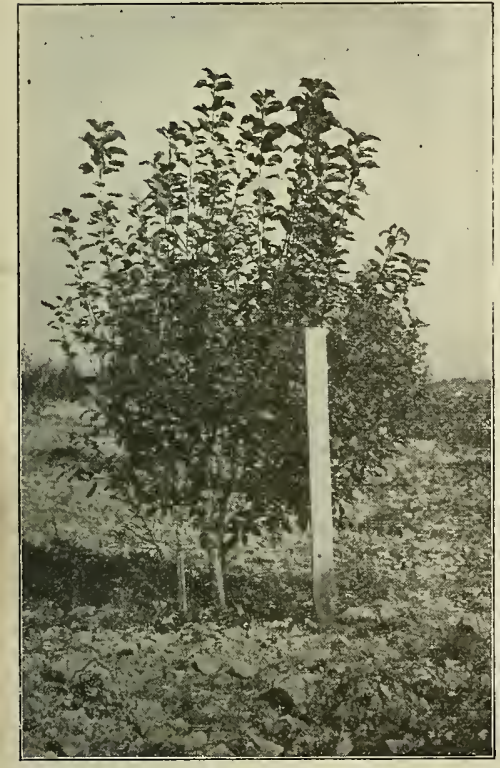

Heavy Dormant Pruning.

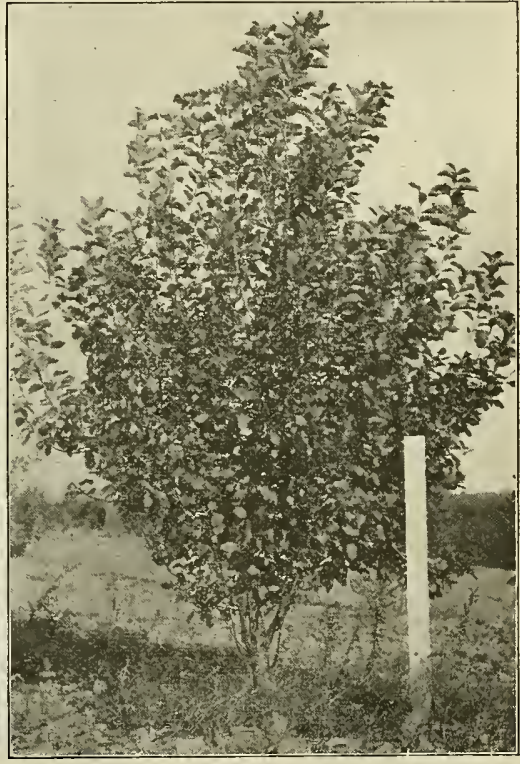

Light Dormant Pruning.

BY .

W. H. Alderman and E. C. Auchter 


\title{
THE STATE OF WEST VIRGINIA
}

\author{
Educational Institutions
}

\section{THE STATE BOARD OF CONTROL}

JAMES S. LAKIN, President

A. BLISS McCRUM

Charleston, W. Va.

J. M. WILLIAMSON

Charleston, W. Va.

Charleston, W. Va:

The State Board of Control has the direction of the financial and business affairs of the state educational institutions.

\section{THE STATE BOARD OF REGENTS}

M. P. SHAWKEY, President

State Superintendent of Schools

GEORGF S. LAIDLEY

ARLEN G. SWIGER.

EARL W. OGLEBAY.

JOSEPH M. MURPHY.

Charleston, W. Va.

Charleston, W. Va. Sistersville, W. Va. ..Wheeling, W. Va. Parkersburg, W. Va.

The State Board of Regents has charge of all matters of a purely scholastic nature concerning the state educational institutions.

\section{The West Virginia University}

FRANK BUTLER TROTTER, LL.D.

President

\section{AGRICULTURAL EXPERIMENT STATION STAFF}

JOHN LEE COULTER, A.M., PH.D.

BERT H. HITE, M.S.

W. E. RUMSEY, B.S. Agr.

N. J. GIDDINGS, M.S

HORACE ATWOOD, M.S. Agr

I. S. COOK, JR., B.S. Agr.

W. H. ALDERMAN, B.S. Agr.

L. M. PEAIRS, M.S

E. W. SHEETS, B.S. Agr., M.S.

FIRMAN E. BEAR, M.Se

C. A. LUEDER, D.V.M.

$\uparrow$ L. I. KNIGHT, PH.D.

A. L. DACY, B.Sc.

FRANK B. KUNST, A.B.

CHARLES E. WEAKIEY, Jr.

J. H. BERGHIUS-KRAK, B.SC.

GEORGE W. BURKE, B.S

ROBERT M. SALTER, M.Sc.

ANTHONY BERG, B.S.

E. C. AUCHTER, B.S. Agr.

L. F. SUTTON, B.S., B.S. Agr.

H. L. CRANE, B.S. Agr.

W. B. KEMP, B.S. Agr

HENRY DORSEY, B.S. Agr., M.S. Agr.

E. L. ANDREWS, B.S. Agr.

*A. J. DADISMAN, M.S. Agr.

J. J. YOKE, B.S. Agr.

R. H. TUCKWILLER, B.S. Agr.

A. C. RAGSDALE, B.S. Agr.

A. J. SWIFT, M.S. Agr

*C. H. SCHERFFIUS.

A. B. BROOKS, B.S. Agr

C. E. STOCKDALE, B.S. Agr

W. J. WHITE

Director

Vice-Director and Chemist State Entomologist Plant Pathologist Poultryman

Consulting Agronomist Horticulturist

Research Entomologist Animal Industry Soil Investigations Veterinary Science Plant Physiologist Associate Horticulturist ..Assistant Chemist Assistant Chemist Assistant Chemist Assistant Chemist Assistant Soil Chemist Assistant Plant Pathologist Assistant Horticulturist Assistant Horticulturist Assistant Horticulturist Assistant Agronomist Assistant Agronomist ssistant in Poultry Husbandry Farm Management Assistant in Animal Industry Assistant in Animal Industry Assistant in Animal Industry

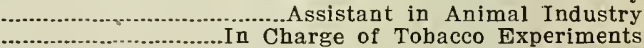
tIn co-operation with the University of Chicago.

* In co-operation with United States Department of Agriculture, 


\title{
The Apple as Affected by Varying Degrees of Dormant and Seasonal Pruning
}

\author{
By W. H. ALDERMAN and E. C. AUCHTER.
}

\section{INTRODUCTION.}

Probably one of the oldest and most universally practiced of orchard operations is pruning. Earliest records in horticulture contain repeated references to this practice, and no modern writer would think of publishing a general treatise on orcharding without devoting a considerable portion of it to detailed directions regarding pruning operations. Like many other phases of horticulture, the subject of pruning has been so much discussed that original information has been lost sight of and oft-repeated theories and statements of general observations have been blindly accepted as fundamental facts around which have been formulated far-reaching principles of plant growth. That much teaching has probably been erroneous is not to be wondered at; the surprising thing is that so much has been correct. The greater is the surprise when, after a long search through foreign and American writings, are found, out of the vast amount of published material, barely a scant half dozen accounts of well-planned experimental work having to do with the pruning of the apple, while the other tree fruits are even less well provided for. The meager results secured from these experiments in widely separated parts of the world are not always clear cut and have had little effect in molding the current theories and principles of pruning. The more important details of some of these experiments will be considered later in connection with the work of the West Virginia Agricultural Experiment Station.

\section{OUTLINE OF THE WEST VIRGINIA EXPERIMENTS.}

History. In the spring of 1911, A. L. Dacy, then assistant horticulturist at the West Virginia Agricultural Experiment Station, began a pruning experiment in an orchard on the farm of Arthur Sheets at Lost Creek, West Virginia. This orchard is located on a side hill in a Westmoreland silty clay loam soil of only moderate fertility and is typical of many 
West Virginia plantings. The orchard was put out in the spring of 1909, but the trees in that portion of the orchard in which the pruning experiment was later located were nearly all destroyed by rabbits during the ensuing summer and winter. Of the replants in 1910 a few were lost so that it was not until 1911, the time of the beginning of the experiment, that the trees were all in place. At the time it was not appreciated that the differences in the ages of the trees would seriously affect the experiment, but it has now been found necessary to eliminate from consideration all data secured from trees not planted in 1910 and which were one year old at the time the first experimental pruning was made. This elimination has reduced the number of trees from forty-five to twenty-three, a number all too small upon which alone to base final conclusions. Fifteen trees of each of the three varieties, York Imperial, Grimes, and Rome, were originally included but the reduction leaves seven, seven, and nine trees respectively. The orchard was planted in corn as an intercrop in 1911, followed by a cover crop of crimson clover. In 1912 it was seeded down and has been in sod ever since, a small crop of hay having been removed annually. Tree growth during the past two years has been somewhat lessened by this practice.

In the spring of 1912 the experiment was greatly extended by adding four other orchards to the test. The first of these was a young orchard planted in 1911 upon property now owned by the Berkeley Springs Orchard Company of Berkeley Springs, West Virginia. The soil in this orchard is a rather thin gravelly or shaley clay loam of about the same fertility as that in the Sheets orchard. The land, except in one spot where a small depression has forced the elimination of a little over one-half of one plot, slopes quite uniformly and gently to the east. The experiment originally included one hundred and eighty-seven trees, somewhat unequally divided among the varieties, Stark, Gravenstein, Rome, and Stayman Winesap, but the above-mentioned soil inequality and the usual run of accidents to growth and development have rendered it necessary to discard thirty-six trees, thus leaving one hundred and fifty-one trees which are uniform and comparable in every way. The orchard was planted in an intercrop of corn in 1911 with cowpeas planted at the last cultivation as a cover crop. In 1912 and 1913 tomatoes were planted as intercrops, followed by crimson clover sowed at the last cultivation. In 1914 the clover was allowed to stand and was plowed under after it had made a good growth. In 1915 tomatoes were again grown and were followed by a cover crop of rye. 
The two orchards already described have furnished material for a study of the effects of pruning up to bearing age upon the trees. The next two orchards to be described taken together illustrate the influence of pruning upon orchards just coming into bearing. These orchards, the one belonging to Lupton Brothers and the other to the Grimes Golden Orchard Company, are both near Martinsburg, West Virginia, and are located upon fertile limestone soil, the surface of which is broken by numerous limestone outcrops. In the Lupton orchard a block of ninety York Imperial, six years old, was chosen. The soil treatment in this orchard consisted of cultivation each year with occasionally a crop of corn between the rows. A strip of sod, however, was left in each of the tree rows. In the Grimes Golden orchard two blocks of fortyfive trees each of seven-year-old York Imperial and Grimes were chosen. The choice was an unfortunate one, however, as the Grimes row subsequently bore so many Gano apples that it was found necessary to abandon it bodily. In the York Imperial block some trees not true to name were found, so that the total number of trees was reduced to thirty-seven. The cultural treatment in this block has been sod in 1912 . sod with tree rows cultivated in 1913, and cultivation followed by good natural weed cover crops in 1914 and 1915 .

The fifth test was in C. W. Boyer's orchard at Bunker Hill, West Virginia, and furnishes an opportunity for a study of the effects of pruning on older bearing trees. The orchard is somewhat elevated over the general level of the Shenandoah valley and is on fertile limestone soil. Thirty-five trees each of fifteen-year-old York Imperial and Arkansas (Mammoth Black Twig) varieties were selected for the test. The trees were not in a very vigorous condition at the beginning of the experiment but under the influence of cultivation, leguminous cover crops, and some fertilization, the entire orchard is now in excellent condition. Only two crops of Arkansas, in 1914 and 1915, and one very heavy crop of York Imperial, in 1914, have been secured, apple rust and the disastrous freeze of 1913 being responsible for the failures. Lack of uniformity in development, obviously not due to pruning, and mixed varieties have led to the discarding of three trees in this orchard.

The accompanying table indicates the number of trees of each variety in the several orchards together with the treatment accorded each plot. 


\section{TABLE I.-The Number of Trees and Varieties in Each Plot.}

\begin{tabular}{|c|c|c|c|c|c|c|c|c|c|c|c|}
\hline \multirow[b]{2}{*}{$\begin{array}{l}\text { PRUNING } \\
\text { TREATMENT }\end{array}$} & \multicolumn{3}{|c|}{ Sheets Orchard } & \multicolumn{4}{|c|}{$\begin{array}{l}\text { Berkeley Springs } \\
\text { Orchard }\end{array}$} & \multirow{2}{*}{ 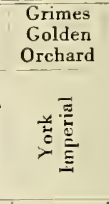 } & \multirow{2}{*}{ 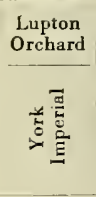 } & \multicolumn{2}{|c|}{$\begin{array}{l}\text { Boyer } \\
\text { Orchard }\end{array}$} \\
\hline & 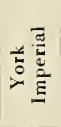 & 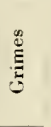 & 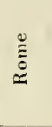 & $\frac{n}{\frac{H}{n}}$ & 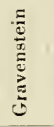 & $\stackrel{\Xi}{\Xi}$ & 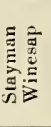 & & & 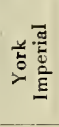 & 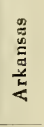 \\
\hline Heavy dormant & 1 & 2 & 4 & 19 & 17 & 13 & 24 & 5 & 10 & 5 & 5 \\
\hline IModerate dormant.. & 2 & 1 & 2 & .... & 7 & 8 & 19 & 5 & 10 & 5 & 5 \\
\hline Light dormant...--...... & 1 & 2 & 3 & 4 & 10 & 11 & 19 & 5 & 9 & 5 & 5 \\
\hline $\begin{array}{l}\text { Heavy dormant and } \\
\text { early summer........ }\end{array}$ & -.- & $\cdots$ & ( & 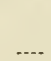 & (-. & 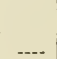 & & 1 & 9 & 5 & 4 \\
\hline Moderate dormant & & & & & & & & & & & \\
\hline and early summer & .... & .... & .... & -.-- & --- & -... & $\cdots-\cdot$ & 2 & 10 & 4 & 5 \\
\hline Early summer & :... & $\cdots-$ & $\cdots$ & $\cdots$ & $\cdots .$. & $\cdots$ & --.. & 5 & 10 & 5 & 5 \\
\hline Midsummer ............! & 3 & 2 & -... & -... & .... & -..- & --.- & 5 & 10 & 4 & 5 \\
\hline Repeated summer & -... & $\cdots$ & $\cdots$ & -..- & $\cdots$ & .... & .... & 4 & 10 & $\cdots$. & .... \\
\hline Ringing ................. & 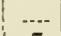 & $\ldots$ & $\ldots$. & $\ldots$ & $\cdots$ & $\cdots$ & .... & 5 & 10 & .... & .... \\
\hline Total & 7 & 7 & 9 & 23 & 34 & 32 & 62 & 37 & 88 & 33 & 34 \\
\hline
\end{tabular}

Total number of trees under experimentation

$-366$

Definition of Treatment. Before considering the results of the experiment it is necessary first to designate clearly what was actually done with the several plots in order to furnish a basis for an interpretation of the results and for a comparison with other experiments. In the Berkeley Springs orchard the three general plots receiving heavy dormant, moderate dormant, and light dormant pruning were subdivided into a number of minor divisions based upon the amount of heading back of terminal growth practiced in addition to the normal branch thinning. The amounts of terminal growth removed are as follows:

\section{Terminal Growth Removed in Heavy Pruning.}

Plot A.-Three-fourths annually for five years, followed by branch thinning only.

Plot B.-Two-thirds annualiy for five years, followed by branch thinning only.

Plot C.-One-half annually for five years, followed by branch thinning only.

Plot D.-Three-fourths first year, two-thirds second year, onehalf third year, one-third fourth year, one-fourth fifth year, followed by branch thinning only.

\section{Terminal Growth Removed in Moderate Pruning.}

Plot E.-One-fourth annually for five years, followed by branch thinning only.

Plot F.-Two-thirds first year, one-third second year, onefourth third year, followed by branch thinning only. 
Plot G.-One-half first year, one-third second year, one-fourth third year, followed by branch thinning only.

\section{Termina! Growth Removed in Light Pruning.}

Plot H.--One-half first year, one-fourth second year, followed by branch thinning only.

Plot I.--One-fourth first year, followed by branch thinning only.

Plot J.-Not headed back, branch thinning only.

It soon became apparent that it was not practicable to make such small variations in treatment in orchards not entirely under the control of the Agricultural Experiment Station and so far removed from headquarters. Consequently only the general grouping of heavy, moderate, and light pruning will be considered in this bulletin. In the Sheets orchard the heavy pruning corresponds to plot $\mathrm{D}$ in the preceding outline, moderate pruning to plot $F$, and light pruning to plots $I$ and $J$.

In the Grimes Golden orchard and the Lupton orchard heavy pruning was secured by a severe thinning and heading back of the new growth each year, except in 1915 when heading back was discontinued. It is extremely difficult to maintain a system of heavy pruning upon bearing trees without. removing a large amount of bearing wood and thus checking seriously the fruitage of the tree. This fact led after two or three years to a gradual reduction of the severity of this type of pruning. A proper relation, however, was always maintained between the heavy, moderate, and light pruning. The moderate pruning in these orchards included a slight heading back of terminal growth the first few years; but in the light pruning, branch thinning only was practiced with no heading back. On the bearing trees in the Boyer orchard no heading back was performed, the difference between heavy, moderate, and light pruning being secured by varying the amount of branch thinning. In all orchards dormant pruning took place between March 20 and April 4 of each year.

The summer pruning practiced was of practically the same type as the dormant pruning and in amount of wood removed corresponded closely with the moderate dormant pruning. The early summer pruning was performed in 1912 and 1913 between May 25 and May 31 but in the last two years was shifted to June 9 to 11 , as the earlier pruning seemed to be much too early. The midsummer pruning took place each year between July 8 and 15, while the repeated summer pruning was simply a combination of the early and midsummer prunings and took place on the dates mentioned. In this region fruit bud formation in the apple begins from June 20 to July 1. Early summer pruning was performed just previous 
to this period and midsummer pruning just following it after the period of most rapid growth was completed. It will be noted that, in two orchards, ringing was practiced. This phase of the work consisted of the removal, at the time of the early summer pruning, of a narrow strip of bark around the trunk of each tree and near the ground. During this girdling operation care was taken not to injure the cambium, the soft sappy layer of tissue next to the wood. Ringing was performed but once only on each tree.

\section{PART I.-The Effects of Varying Degrees of Dormant Pruning upon Trees of Different Ages.}

\section{The Effects of Heavy, Moderate, and Light Pruning upon the First Five Years' Growth of Trees.}

The data presented under this head are taken entirely from the Berkeley Springs and Sheets orchards. It will be noted that the results are much more clearly cut in the former orchard than in the latter. It is thought that too few trees were used in the Sheets orchard to overcome tree individuality and small inequalities in soil fertility which are difficult to detect but which are very liable to occur upon a hillside. The results obtained in the Berkeley Springs orchard, which is planted in a more uniform soil and contains a greater number of trees, impress the writers as being much more indicative of true conclusions than do the results of the Sheets experiment.

Character of Annual Terminal Growth and Amount of Wood Removed. It was observed throughout the experiment wherever heavy pruning was performed and particularly where the heading back was severe that a rank terminal growth was secured. This result is strictly in accord with general teaching and observation and has undoubtedly led to establishing firmly in the professional's as well as in the layman's mind the principle that heavy pruning tends to increase the production of wood. Most.certainly at first glance this would appear to be true but it will be shown later that the conclusion is probably due to an optical illusion caused by the rank growth of a few branches. Table II shows data upon the annual terminal growth taken from the Sheets orchard only. 
TABLE II.-Average Length of Annual Terminal Growth with Length, Weight, and Number of Branches Removed per Tree. (Sheets Orchard.)

Average Length of Terminal Growth (Inches).

\begin{tabular}{|c|c|c|c|c|c|}
\hline 1911 & 1912 & 191.3 & 1914 & 1915 & Average \\
\hline ......................... & 42.6 & 39.2 & 24.7 & 23.5 & 32.3 \\
\hline ng .................. & 40.6 & 20.8 & 14. & 13.5 & 22.2 \\
\hline ght prunin & 29.4 & 15.5 & 9.3 & 9.9 & 16.0 \\
\hline
\end{tabular}

Average Length Removed (Feet).

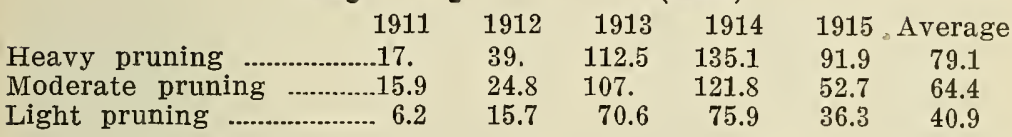

Average Weight Removed (Pounds).

\begin{tabular}{|c|c|c|c|c|c|}
\hline 1911 & 1912 & 1913 & 1914 & 1915 & Average \\
\hline eavy pruning ..... & .... & 2.57 & 2.26 & 1.36 & 2.06 \\
\hline Moderate pruning .............. & .... & 2.25 & 1.6 & .68 & 1.51 \\
\hline Light pruning ..................... & & 1.46 & 1.5 & .54 & 1.17 \\
\hline
\end{tabular}

Average Number of Branches Removed.

$\begin{array}{lrrrrrc} & 1911 & 1912 & 1913 & 1914 & 1915 & \text { Average } \\ \text { Heavy pruning ..................... } 7.7 & 26.7 & 39.3 & 81.4 & 71.4 & 45.3 \\ \text { Moderate pruning } & \text {................ } & 32.6 & 46.8 & 84.2 & 41.6 & 45 . \\ \text { Light pruning ................... } & 15.1 & 33.5 & 43.3 & 27.7 & 24.5\end{array}$

In this orchard the pruning was heaviest at the beginning and gradually decreased as the orchard grew older. The increase in size of the trees more than offset this, however, so that the amount of wood removed in terms of length, weight, and number of branches increased each year until in 1915, when there was a marked decrease. This decrease was due partly to the fact that the trees made a slightly less than normal growth in 1914 and partly to a general lightening of pruning in trees of that age.

Total Length of Annual Growth. As a quantitative measure of the growth of the trees each year, one variety (Stark) was selected in the Berkeley Springs orchard and each year careful measurements of the total new longitudinal growth were taken together with the amount of this growth removed at the annual prunings. It must be understood that this does not represent an exact measure of the volume of wood produced each year for the heavily pruned trees produced fewer but larger shoots than were produced upon the lightly pruned trees. Consequently the longitudinal growth of the heavily pruned blocks weighed more per running foot than did that of the lightly pruned blocks. This difference in character of the terminal growth is more than offset by the annual increase in diameter of the main branches. These branches in the 
lightly pruned trees are longer, not having been headed back, and consequently the total volume of the ring of new growth put on by them is greater than that on the heavily pruned trees. It is interesting to note from Table III that for the first two years, 1912 and 1913, the heavily pruned trees produced as much as or slightly more growth than did the lightly pruned trees.

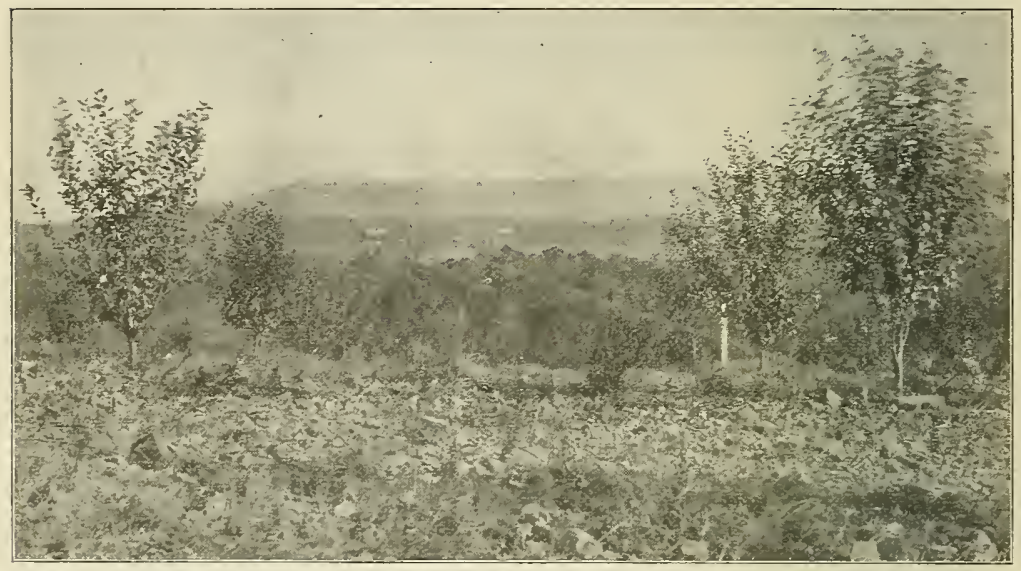

Fig. 1.-Row on Left Heavily Pruned, Row on Right Lightly Pruned (Stark Variety).

Unfortunately the lightly pruned plot at one end dipped into a depression where the soil seemed to be richer and growth was correspondingly greater than in the remainder of the plot. To overcome this difficulty a number of trees were discarded so that this plot finally contained four trees and the heavily pruned plot contained nineteen trees.

TABLE III.-Average Total Length per Tree of Annual Longitudinal Growth and Length in Feet Removed Each Year. (Stark Variety).

\begin{tabular}{|c|c|c|c|c|c|c|c|}
\hline \multicolumn{4}{|c|}{ HEAVY PRUNING } & \multicolumn{4}{|c|}{ LIGHT PRUNING } \\
\hline $\begin{array}{l}\text { Season } \\
\text { of } \\
\text { Growth }\end{array}$ & $\begin{array}{l}\text { Average } \\
\text { Total } \\
\text { Length of } \\
\text { Growth }\end{array}$ & $\begin{array}{l}\text { Average } \\
\text { Length } \\
\text { Removed }\end{array}$ & $\begin{array}{c}\text { Percent } \\
\text { Re- } \\
\text { moved }\end{array}$ & $\begin{array}{l}\text { Average } \\
\text { Total } \\
\text { Length of } \\
\text { Growth }\end{array}$ & $\begin{array}{c}\text { Average } \\
\text { Length } \\
\text { Removed }\end{array}$ & $\begin{array}{c}\text { Percent } \\
\text { Re- } \\
\text { moved }\end{array}$ & $\begin{array}{c}\text { Gain in Feet } \\
\text { Over } \\
\text { Heavy Pruning }\end{array}$ \\
\hline 1911 & 4.41 & 3.3 & 74.8 & 5.58 & 3.44 & 61.6 & \\
\hline 1912 & 16.25 & 12.91 & 79.4 & 15.51 & 4.78 & 31.4 & $-\quad .74$ \\
\hline 1913 & 41.53 & 33.16 & 79.8 & 34.33 & 13.89 & 41.4 & -7.20 \\
\hline 1914 & 84.08 & 49.17 & 58.4 & 99.39 & 22.12 & 22.2 & +15.31 \\
\hline 1915 & 161.74 & ......... & ...... & 224.89 & ......... & ....... & +63.15 \\
\hline
\end{tabular}


It appears quite clear from this table that the removal of about $75 \%$ of the new growth at the first and second prunings (pruning at planting time not considered) may have a beneficial effect upon tree growth but that after that time severe pruning should be avoided.

In order to see if light pruning produced the same tendency toward greater growth in other varieties, careful measurements were made of the total longitudinal growth produced in 1915 on a considerable number of trees in each orchard. The results of this study are shown in detail in Table IV. While there is some deviation in the case of the Gravenstein at Berkeley Springs and in the mixed York Imperial, Rome, and Grimes block in the Sheets orchard, it can be plainly seen that the general tendency is to put on a new growth in inverse ratio to the amount of wood removed.

TABLE IV.-Average Tota! Length per Tree in Feet of Longitudinal Growth in 1915.

$\begin{array}{lrcrc}\quad \begin{array}{c}\text { No. of } \\ \text { Vrees }\end{array} & \begin{array}{c}\text { Heavily Prun- } \\ \text { ed Trees }\end{array} & \begin{array}{c}\text { No. of } \\ \text { Trees }\end{array} & \begin{array}{c}\text { Lightly Prun- } \\ \text { ed Trees }\end{array} \\ \text { Stayman Winesap } & 11 & 125.12 & 12 & 152.93 \\ \text { Rome } & 6 & 120.75 & 7 & 174.86 \\ \text { Gravenstein } & 6 & 144.66 & 10 & 121.75 \\ \text { Stark } & 161.74 & 4 & 224.89 \\ \text { York Imperial, Grimes, and } & & & & \\ \quad \text { Rome in Sheets Orchard } & 7 & 204 . & 6 & 188 . \\ \text { Average for all varieties... } & & 131.25 & & 172.49\end{array}$

Size and Form of Trees. It would appear from Table III that the heavily pruned trees averaged less annual longitudinal growth than did the others and as they were cut back severely they consequently should be somewhat smaller in size. Casual observation indicated this to be true but to avoid any mistake the heights and widths of all trees in the two orchards were measured in 1915 at the close of the season's growth.

\section{TABLE V.-Average Height and Width of Trees.}

\begin{tabular}{|c|c|c|c|c|}
\hline Variety & $\begin{array}{l}\text { Type of } \\
\text { Pruning }\end{array}$ & $\begin{array}{l}\text { No. of } \\
\text { Trees }\end{array}$ & $\begin{array}{l}\text { Height } \\
\text { in Feet }\end{array}$ & $\begin{array}{l}\text { Width } \\
\text { in Feet }\end{array}$ \\
\hline 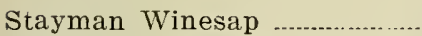 & Heavy & 24 & 7.32 & 5.29 \\
\hline Stayman Winesap & Moderate & 19 & 7.89 & 5.52 \\
\hline Stayman Winesap ...... & Light & 19 & 9.50 & 5.65 \\
\hline Rome & Heavy & 13 & 7.45 & 3.68 \\
\hline Rome & Moderate & 8 & 8.18 & 4.17 \\
\hline Rome & Light & 11 & 9.16 & 4.23 \\
\hline Gravenstein & Heavy & 17 & 7.43 & 4.05 \\
\hline Gravenstein & Moderate & 7 & 6.83 & 4.19 \\
\hline Gravenstein & Light & 10 & 8.94 & 4.34 \\
\hline Stark & Heavy & 19 & 7.57 & 5.17 \\
\hline Stark & Light & 4 & 10.79 & 6.85 \\
\hline York Imperial, Grimes, and & Heavy & 7 & 9.55 & 4.83 \\
\hline Rome in Sheets Orchard & Moderate & 5 & 9.73 & 6.17 \\
\hline & Light & 6 & 10.50 & 7.10 \\
\hline
\end{tabular}


It will be seen from Table $V$ that in no instance is the height or width of trees as great in the case of heavy and moderate pruning as it is in the case of light pruning (see illustration on cover and figs. 1,2, and 3) and in only one instance, height of Gravenstein trees, is moderate pruning exceeded by heavy pruning. In the latter instance the width of the moderately pruned Gravenstein is greater than that of the heavily pruned trees.

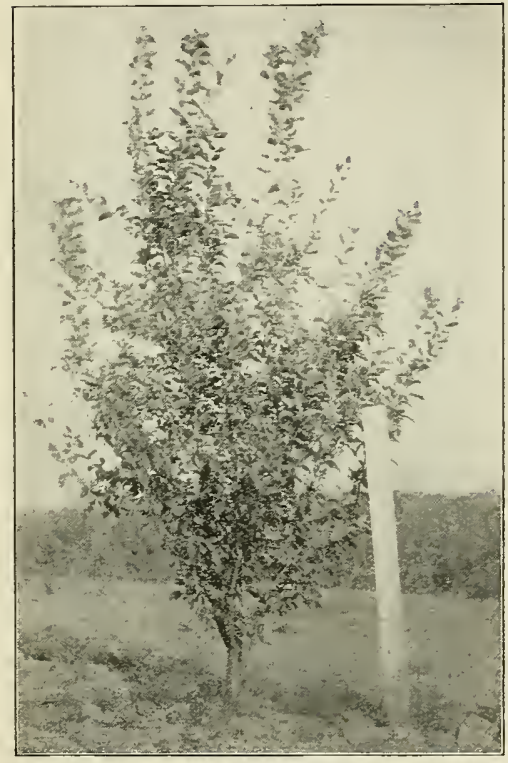

Fig. 2. - Stayman Winesap Given Light Annual Dormant Pruning.

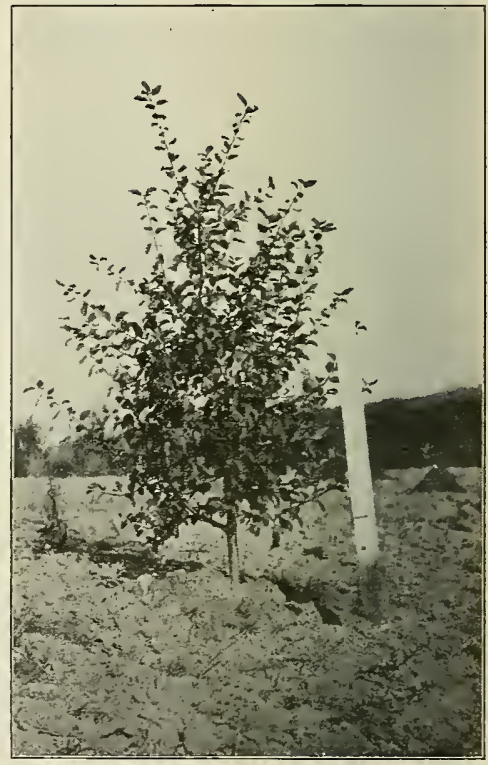

Fig. 3.-Stayman Winesap Given Heavy Annual Dormant Pruning.

Effect upon Form of Tree. The question naturally arises as to what effect heavy and light pruning, particularly heavy and light heading back, may have upon the form of trees. The effect is more easily illustrated than described. Figures 4 to 15 show typical trees of the different groups as they appeared each year. It is noticeable that the primary limb scaffold branches are longer following light pruning than following heavy pruning, and that the secondary branches start out at a greater distance from the trunk. This gives the tree a sprawling habit during the first few years which is in sharp contrast to the compact, neatly-built trees in the more heavily pruned plots. After the third or fourth year, however, this difference is not so noticeable, due to the thickening of scaffold limbs and the filling in of laterals in the lighter pruned 


\section{HEAVILY PRUNED STAYMAN WINESAP.}

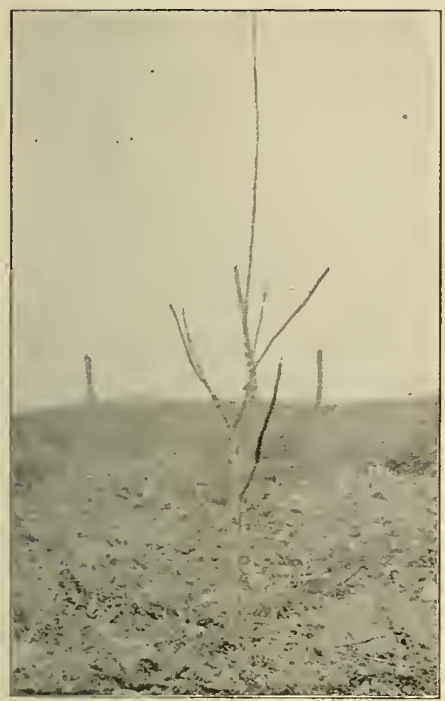

Fig. 4.-After Pruning, Spring of 1913.

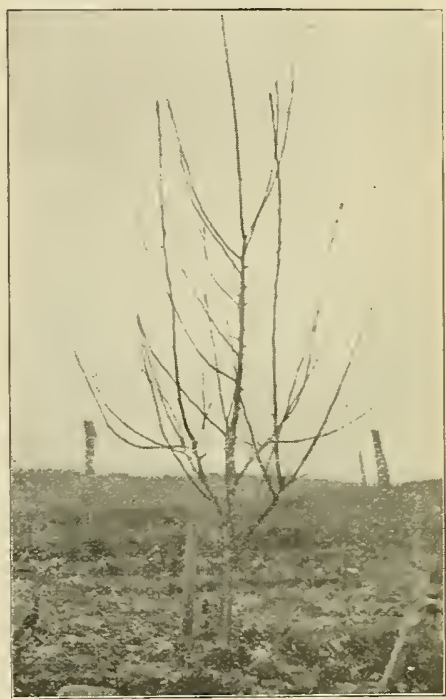

Fig. 5.-Before Pruning, Spring of 1914.

\section{LIGHTLY PRUNED STAYMAN WINESAP.}

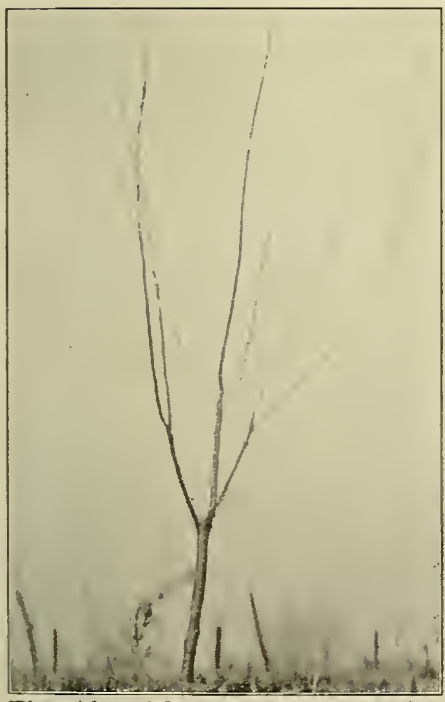

Fig. 10.-After Pruning, Spring of 1913.

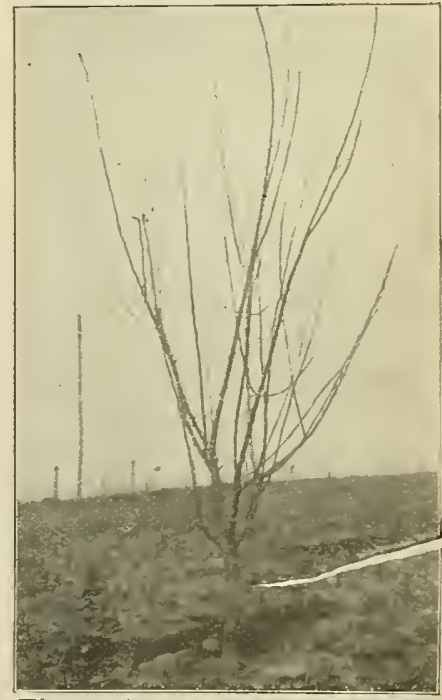

Fig. 11. - Before Pruning, Spring of 1914. 


\section{HEF.VILY PRUNED STAYMAN WINESAP.}

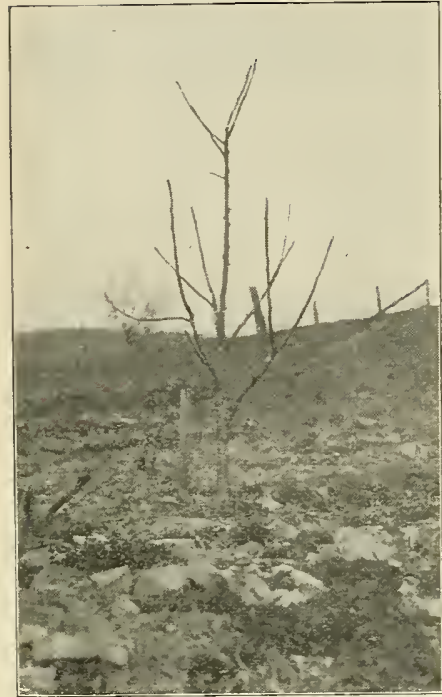

Fig. 6.-After Pruning, Spring of 1914.

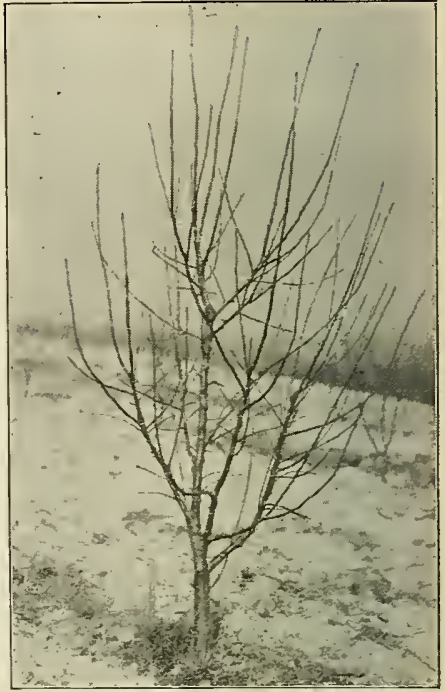

Fig. 7,-Before Pruning, Spring of 1915.

\section{LIGHTLY PRUNED STAYMAN WINESAP.}

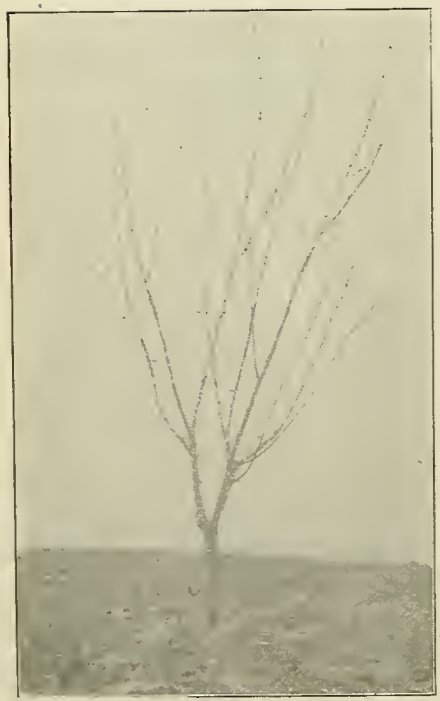

Fig. 12. - After Pruning, Spring of 1914.

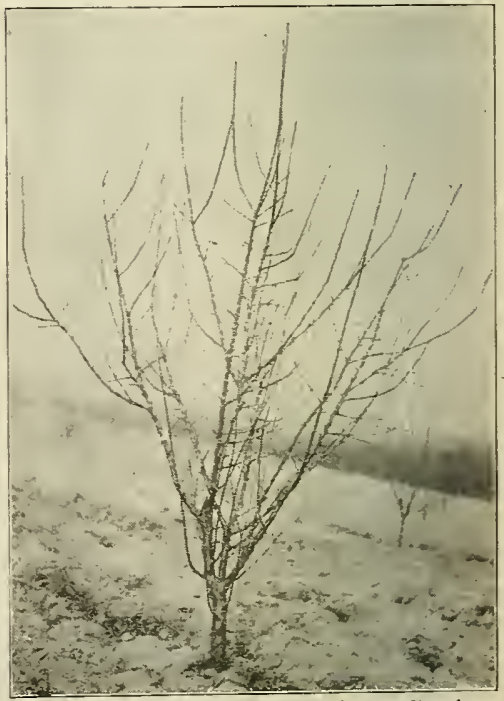

Fig. 13. - Before Pruning, Spring of 1915 . 


\section{HEAVILY PRUNED STAYMAN WINESAP.}

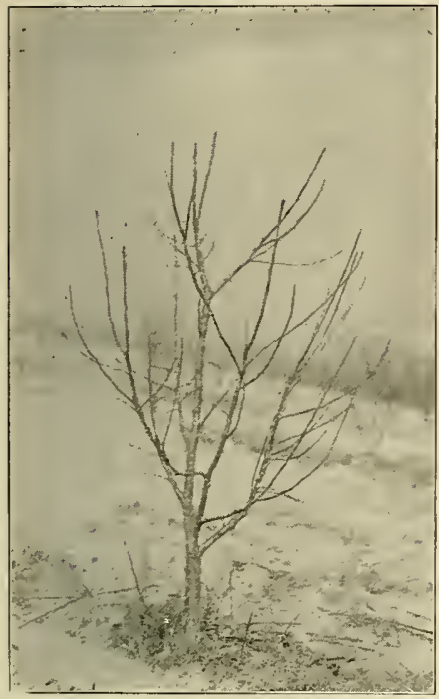

Fig. 8.-After Pruning, Spring of 1915 .

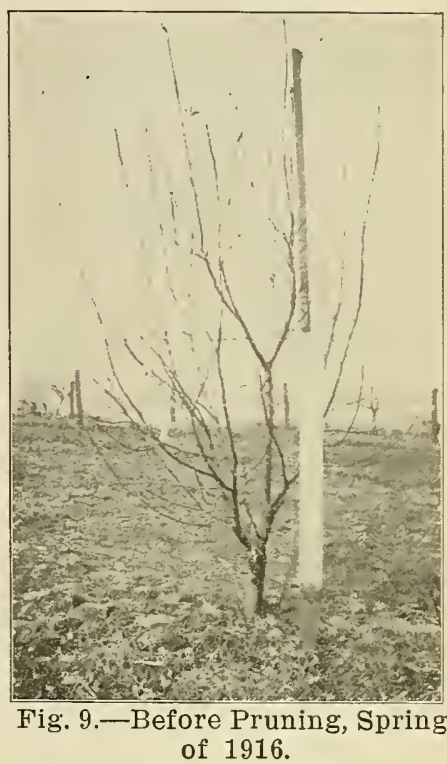

\section{LIGHTLY PRUNED STAYMAN WINESAP.}

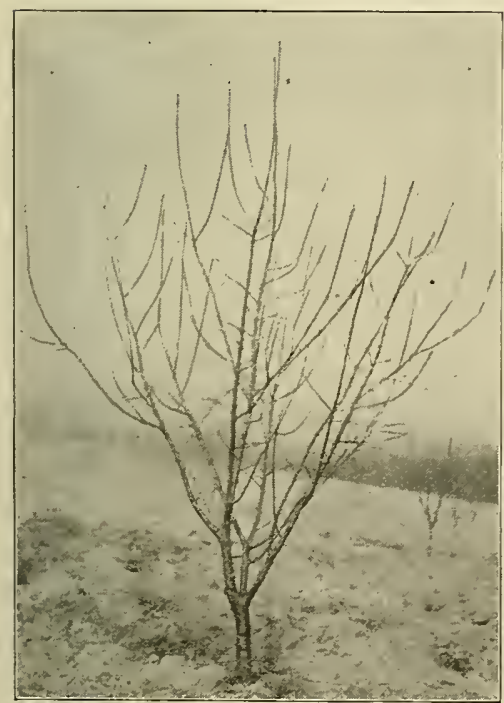

Fig. 14. - After Pruning, Spring of 1915 .

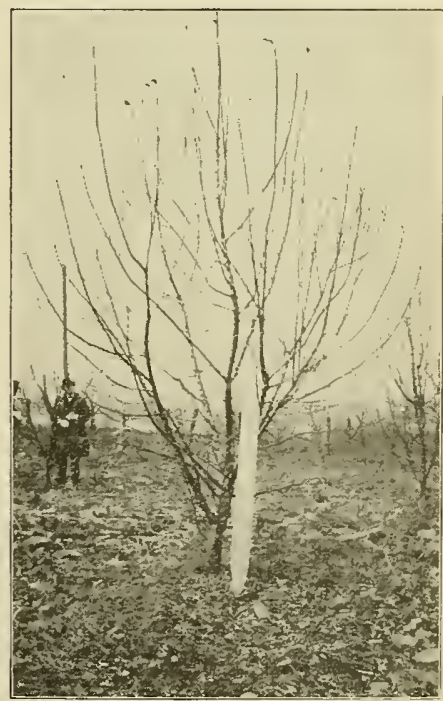

Fig. 15.-Before Pruning, Spring of 1916. 
trees. It is doubtful if trees which have not been headed back at all the first or second year will ever acquire as satisfactory a form as those the branches of which have been shortened during this period. In the interest of strength and sturdiness of tree, the primary branches should not be too long and the secondary branches should spring not farther than twelve or sixteen inches from the trunk. This can be accomplished only by judicious heading back the first and probably the second seasons. After this time light pruning is to be preferred.

\section{Stockiness as Indicated by Diameter of Trunk and} Branches. Up to this point it has been shown that the individual terminal growth of the heavily pruned trees averages larger than that of the more lightly pruned blocks, but that a greater total length or extension of terminal growth took place under light pruning. It has also been shown that trees pruned lightly are taller and broader than those pruned heavily. So far no data have been presented bearing upon the increase in thickness of trunk or branches. Unless such data are presented it might be argued that the longer longitudinal growth of the lightly pruned plots would result in spindling and weak branches with less total volume of growth than in the heavily pruned plots. In addition to throwing light upon this point it is believed that records showing actual increase in diameter of trunk and perhaps of main branches constitute the most reliable evidence of tree vigor securable without actually removing the tree with its roots from the soil and weighing it.

In the Berkeley Springs orchard records of the diameters of the trunks of all trees have been kept each year, the diameters being taken in each case at a point just below the head. The detailed records of these data are show in Table VI. The trees in the several plots were very uniform in the beginning except those in the moderately pruned Gravenstein and lightly pruned Stark and in this case although undersized at the beginning both blocks overcame the handicap within four years or less.

An interesting feature brought out in Table VI is that there is practically no difference between the three plots in increase of trunk diameter for the first two years of the experiment, but in the year 1914 when the trees were making their fourth season's growth, being their third under experiment, the more lightly pruned trees began to forge ahead. of the others. In 1915 this difference became still more pronounced. This phenomenon corresponds very closely with the way the Stark trees behaved with regard to their total longitudinal growth (see Table III) and confirms the opinion held by the authors that a fairly heavy pruning the first two 
TABLE VI.-Increase in Diameters of Tree Trunks in Inches. (Berkeley Springs Orchard.)

\begin{tabular}{|c|c|c|c|c|c|c|c|c|}
\hline VARIETY & $\begin{array}{l}\text { Type of } \\
\text { Pruning }\end{array}$ & $\begin{array}{c}\text { Number } \\
\text { of } \\
\text { Trees }\end{array}$ & $\begin{array}{l}\text { Diameter } \\
1911\end{array}$ & $\begin{array}{c}\text { Diameter } \\
1912\end{array}$ & $\begin{array}{l}\text { I Diameter } \\
1913\end{array}$ & $\begin{array}{l}\text { r Diameter } \\
1914\end{array}$ & $\begin{array}{l}\text { Diameter } \\
1915\end{array}$ & $\begin{array}{c}\text { Increase } \\
\text { in Four } \\
\text { Years }\end{array}$ \\
\hline Stayman Winesap & Heavy & 24 & .36 & .74 & 1.14 & 1.48 & 1.95 & 1.59 \\
\hline Stayman Winesap & Mod. & 19 & .35 & .75 & 1.15 & 1.56 & 2.06 & 1.71 \\
\hline Stayman Winesap & Light & 19 & .34 & .75 & 1.17 & 1.61 & 2.20 & 1.86 \\
\hline Rome & Heavy & 13 & .34 & .70 & 1.02 & 1.25 & 1.61 & 1.27 \\
\hline Rome & Mod. & 8 & .34 & .72 & 1.13 & 1.47 & 1.97 & 1.65 \\
\hline Rome ... & Light & 11 & .35 & .70 & 1.04 & 1.65 & 2.13 & 1.78 \\
\hline Gravenstein & Heavy & 17 & .32 & .72 & 1.13 & 1.47 & 1.97 & 1.65 \\
\hline Gravenstein & Mod. & 7 & 27 & .71 & 1.05 & 1.32 & 1.90 & 1.63 \\
\hline Gravenstein & Light & 10 & .31 & .72 & 1.11 & 1.38 & 2.27 & 1.96 \\
\hline Stark ... & Heavy & 19 & .33 & .73 & 1.15 & 1.57 & 2.17 & 1.98 \\
\hline Stark & Light & 4 & .28 & .68 & 1.16 & 1.87 & 2.91 & 2.63 \\
\hline \multirow{3}{*}{$\begin{array}{l}\text { Weighted Average } \\
\text { of all varieties.. }\end{array}$} & Heavy & 73 & .34 & .73 & 1.12 & 1.46 & 1.95 & 1.61 \\
\hline & Mod. & 34 & .33 & .73 & 1.11 & 1.49 & 2.02 & 1.69 \\
\hline & Light & 44 & .33 & .72 & 1.12 & 1.59 & 2.26 & 1.93 \\
\hline
\end{tabular}

years is desirable since it does not retard growth and aids in forming a well-shaped tree.

Goethe,* a German investigator, cites a case in which trunk measurements were made of a block of eighty-eight two-year-old apple trees sixty of which had been heavily pruned and twenty-eight lightly pruned. The heavily pruned trees averaged $8.4 \mathrm{~cm}$. in circumference and the lightly pruned ones $9.5 \mathrm{~cm}$. The following year the same trees were remeasured and the heavily pruned ones had gained $1.1 \mathrm{~cm}$. in circumference while the others had increased $2 \mathrm{~cm}$., or a gain of $.9 \mathrm{~cm}$. in favor of light pruning. In another block of threeyear-old apple trees 37 trees had been unpruned and 49 heavily pruned. At the beginning of the fourth season the unpruned trees averaged $10.7 \mathrm{~cm}$. in trunk circumference and the pruned trees averaged $8.6 \mathrm{~cm}$. At the close of the season the unpruned trees had increased $2.6 \mathrm{~cm}$. and the pruned trees $1.1 \mathrm{~cm}$., or a gain of $1.5 \mathrm{~cm}$. in favor of the light or no pruning. The same author called attention to the condition of two groups of sycamore trees, each 20 years old. One group which had been heavily pruned averaged .7 meters in circumference and the other which had been unpruned averaged 1.05 meters.

In 1915 we wished to learn if the main limbs behaved the same as the trunks and increased in diameter inversely as to

- The Effect of Annual Pruning on the Growth of Trees, R. Goethe, Ber. K. Lehranst obst. Wein U. Gartenbau Geisenheim, 1899-1900, pp. 54-56. 
the amount of pruning. To secure this information all the scaffold limbs and the central leaders were calipered just above their point of union at the head. At first, trees having three, four, or five branches were kept separate and comparisons were made only between trees of similar branching habit, but as the relation between heavy and light pruning remained practically the same in each type, the results are thrown.together for the sake of convenience.

TABLE VII.-Diameter in Inches of Main Branches in 1915. (Berkeley Springs Orchard.)

\begin{tabular}{|c|c|c|c|c|}
\hline VARIETY & Heavy & Moderate & Light & $\begin{array}{l}\text { Increase of Light Over } \\
\text { Heavy Pruning }\end{array}$ \\
\hline Stayman Winesap & 1.125 & 1.17 & 1.43 & .305 \\
\hline Rome & .92 & 1.20 & 1.25 & .33 \\
\hline Gravenstein & 1.20 & 1.01 & 1.19 & -.01 \\
\hline Stark & 1.18 & -........ & 1.45 & .27 \\
\hline $\begin{array}{l}\text { Weighted average of all } \\
\text { varieties }\end{array}$ & 1.12 & 1.15 & 1.36 & .24 \\
\hline
\end{tabular}

It is very clear from Table VII that the branch growth on the lightly pruned trees is neither "spindling" nor weak. On the contrary, these lightly pruned trees averaged larger by a quarter of an inch in diameter than did the heavily pruned trees, and if we may judge from the way the trunks are behaving this difference will probably become more pronounced in later years.

It is to be regretted that the data gathered from the Sheets orchard are not as conclusive nor the results as clear cut as in the Berkeley Springs orchard. In fact, the authors at first had serious doubts regarding the propriety of publishing the data secured in the Sheets orchard because of the experimental error to which it is subjected. The original number of trees in the experiment was too small to permit of very accurate work and as a number have since been discarded the results when taken alone mean little. They do, however, tend to bear out in many respects the work in the Berkeley Springs orchard and for this reason it was finally decided to include them in the report. The trunk measurements were not taken each year, but at the close of the 1915 season's growth the circumferences of the trees in the three plots were taken and are shown in Table VIII.

\section{TABLE VIII.-Circumference of Tree Trunks. (Sheets Orchard.)}


In this instance the lightly pruned trees exceeded those heavily pruned by one and one-half inches in circumference. These facts furnish valuable corroborative evidence when taken in connection with the work in the other young orchard.

At the beginning of the experiment the average diameter of the first scaffold limbs was taken at their base. The following year these limbs were again measured as were also the terminal shoots which extended the scaffold limbs. Each subsequent year the diameter of the terminal growth of each main branch was secured and also the diameter of each of the preceding year's growth on these limbs. Thus we are able to study the influence of heavy, moderate, and light pruning not only ufon the diameter of the terminal growth following the prining, but also upon the sections of the branch one, two, three, and four years back from the terminal. It is recognized that heavy pruning involving heading back produces a long and correspondingly thick terminal growth but a more important question is whether it tends to thicken the branch back of the point at which the cut was made. A summary of these measurements is shown in Table $1 \mathrm{X}$.

TABLE IX.-Increase in Inches in Diameters of Main Limbs. (Sheets Orchard.)

HEAVY PRUNING, 7 TREES.

\begin{tabular}{|c|c|c|c|c|c|c|c|c|c|}
\hline \multirow{2}{*}{$\begin{array}{c}\text { Total Age of Branch } \\
\text { Section }\end{array}$} & \multicolumn{5}{|c|}{ Average Increase Each Year } & \multirow{2}{*}{$\begin{array}{l}\text { Average } \\
\text { Yearly } \\
\text { Increase }\end{array}$} & \multirow{2}{*}{$\begin{array}{c}\text { Total } \\
\text { Diame. } \\
\text { ter, } \\
1915\end{array}$} & \multirow{2}{*}{$\begin{array}{c}\text { Average } \\
\text { Increase } \\
\text { After } \\
\text { First } \\
\text { Year }\end{array}$} & \multirow{2}{*}{$\begin{array}{c}\text { Total } \\
\text { Increase } \\
\text { After } \\
\text { First } \\
\text { Year }\end{array}$} \\
\hline & 1911 & 1912 & 1913 & 1914 & 1915 & & & & \\
\hline 5 years & .332 & .198 & .170 & .187 & .102 & .198 & .989 & .164 & .657 \\
\hline 4 years ... & ......... & .408 & .046 & .170 & .124 & .187 & .748 & .113 & .340 \\
\hline 3 years ... & ......... & -........ & .306 & .147 & .082 & .178 & .535 & .115 & .229 \\
\hline 2 years ... & ......... & ......... & …..... & .311 & .071 & .191 & .382 & .071 & .071 \\
\hline 1 year. & .......... & .......... & & …..... & .268 & & ......... & $\cdots$ & -........ \\
\hline
\end{tabular}

MODERATE PRUNING, 5 TREES.

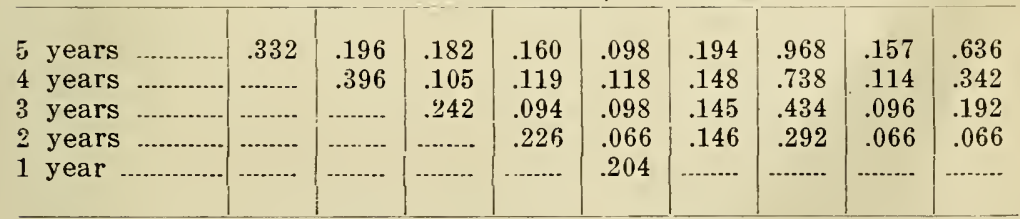

LIGHT PRUNING, 6 TREES.

\begin{tabular}{|c|c|c|c|c|c|c|c|c|c|}
\hline 5 years & .257 & .157 & .161 & .168 & .184 & .185 & .927 & .168 & .670 \\
\hline 4 years & .......... & .296 & .064 & .144 & .123 & .157 & .627 & .110 & .331 \\
\hline 3 years & .......... & .......... & .225 & .096 & .094 & .138 & .415 & .095 & .190 \\
\hline 2 years & ......... & ......... & .......... & .198 & .076 & .137 & .274 & .076 & .076 \\
\hline 1 year. & \begin{tabular}{c|c|} 
& \\
$\ldots$
\end{tabular} & .......... & .......... & $\cdots \cdots$ & .196 & & $-\ldots . . .$. & ........... & -....... \\
\hline
\end{tabular}


Although the data in this table are largely negative in nature there are a few things that should be pointed out as being at least suggestive. First, the table shows that in each case the terminal growth has a greater average diameter when the pruning is heavy. (The diameter of terminal growth is shown by the first decimal in the first column of each line.) Then, ignoring the terminal growth which is always heavy following heavy pruning and referring to the second column from the right side of the table under the caption "Average Increase After First Year" we find that there is practically no difference in favor of any method of pruning. The lightly pruned plot has a slight advantage in the two- and five-yearold sections but loses in the three- and four-year-old sections. It should be noticed that in 1915 the lightly pruned block made a greater increase in its several sections, terminal growth excluded, than did either of the other two blocks. This may support previous evidence that heavily pruned trees make better growth the first year or two but that lightly pruned trees overtake and pass them by the third to fifth season.

It may be worth while to refer at this point to work* done at the English Experimental Fruit Farm at Woburn. A large number of terminal shoots 36 inches long were selected. These shoots were divided into four groups, the first of which was headed back to 6 inches, the second to 12 inches, the third to 24 inches, and in the fourth the terminal bud only was removed. After one season's growth the basal enlargements of each original shoot were measured and were fuund to bear the following relation to each other:

6-inch group
12-inch group
24 -inch group
36-inch group

As these comparisons were made from branches on the same tree they would seem to indicate pretty definitely that the lighter the pruning, the greater will be the increase in diameter of wood growth back of the cut. This is strictly in accordance with the work in the Berkeley Springs orchard, and as far as trunk measurements are concerned also in the Sheets orchard, except in this work the increase in favor of light pruning was sometimes deferred for two or more years. It should be stated that the trees in the Noburn experiment just quoted were of bearing age while.the ones in this experiment were not yet in bearing.

Early Bearing. The trees in both orchards are too young to have produced much fruit up to this time. but a small

*Bedford and Pickering, Woburn Experimental Fruit Farm, Seventh Report, 1907. 
amount has been secured from the Sheets orchard and a few specimens formed in the Berkeley Springs orchard in 1915 but were picked off by the owners so as not to check tree development. In both orchards some bloom was found in 1914 and 1915, and a good set of fruit buds has been recorded for the 1916 crop.

\section{TABLE X.-Effect of Pruning upon Early Bearing. (Berkeley Springs Orchard).}

\section{VARIETY \\ Type}

Stayman Winesap.. Heavy

Stayman Winesap.. Moderate

Stayman Winesap.. Light

Rome

Rome

Heavy

Rome

Moderate

Light

Gravenstein

Gravenstein

Gravenstein

Stark

Stark
Heavy

Moderate Light

Heavy

Light

Bloom Clusters
Per Tree, 1914
0
.16
.05
0
1.6
2.4
0.
0
0
0
0

Percent Bloom Per Tree, 1915

Percent Fruit Buds - Per Tree, 1916

TABLE X1.-Effect of Pruning upon Early Bearing. (Sheets Orchard.)

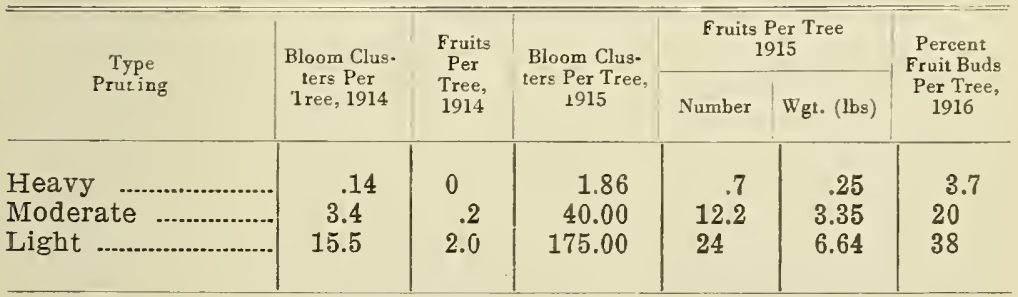

Table X and Table XI need little explanation. In both orchards the results are exactly the same and in both cases light pruning has shown a strong tendency to induce early bearing and heavy pruning has retarded bearing. In the Woburn experiment already referred to, similar results were secured on dwarf trees. In that experiment, records for 12 years were reported in three periods. The yield of the moderately pruned trees was taken as 100 and proportional values were: attached to the other groups with the following results:

1st 5 Yrs. 2nd 5 Yrs. 12th Yr.

\begin{tabular}{|c|c|c|c|}
\hline Heavy pruning ......... & 75 & 50 & 5 \\
\hline Moderate pruning & 100 & 100 & 100 \\
\hline 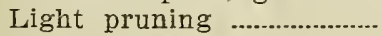 & 90 & 150 & 145 \\
\hline No pruning & 220 & 200 & 275 \\
\hline
\end{tabular}


The same experiment station reported the yields of 53 varieties of standard and 80 varieties of dwarf trees for one year, contrasting moderate and heavy pruning.

$\begin{array}{lcc} & \text { Standards } & \text { Dwarfs } \\ \text { Heavy pruning } & 28 & 30 \\ \text { Moderate pruning } & -\ldots-\ldots & 100\end{array}$

There can seem to be no question that young apple trees if given little or no pruning will come into bearing earlier than if pruned heavily.

Volume of Growth Affected by Pruning. In measuring the effect of pruning or of any other factor upon tree growth, a single set of measurements is often of little value. The true vigor of the tree can only be determined by finding the actual volume or weight of new tissue formed. In young trees this volume is confined to the leaves and to the wood of tops and roots. In older trees the fruit must, of course, be also considered. There is no feasible way of measuring exactly the yearly increase in new tissue without actually digging up a number of trees each season, but a comparative estimate that is reasonably accurate may be made if sufficient data have been secured. Regarding the young trees in the two orchards under discussion five salient facts were determined by sufficiently careful measurements. First, the lightly pruned trees are taller and broader than those heavily pruned. Second, the lightly pruned trees have annually made the longer total growth. Third, the main branches of the lightly pruned trees though longer are larger in diameter than those of the heavily pruned plots. Fourth, the lightly pruned trees have the larger trunks. Fifth, while little or no fruit has been produced, the lightly pruned trees have exhibited a tendency toward early bearing, as eridenced by bud, and flower formation, and heavy pruning has shown a tendency to retard bearing. No measurements of root growth have been possible but since the lightly pruned trees are the larger, have made the longer annual growth, have the thicker limbs and trunks, and have shown the greater tendency toward fruitfuniness, it can only be concluded that they are making the greater annual production of new tissue.

The Woburn Experiment Station* in its seventh report gives corroborative data upon the point under discussion. After dwarf trees had been under experiment 12 years, it was found necessary to thin the planting and the opportunity was taken to weigh carefully the trunks and branches and as much of the

*Bedford and Pickering, Woburn Experimental Fruit Farm, Seventh Report, 1907. 
root systems as was formed within a radius of 18 inches from the trunks. The heavily pruned trees were found to be $16 \%$ lighter than the moderately pruned trees, while those left unpruned were $20 \%$ heavier than those moderately pruned. Estimates were made of the amount of wood removed in pruning and, as the total weight of this wood did not nearly equal the difference in weight of the trees, it was assumed that the unpruned trees had actually produced more new tissue during the 12 years than had the ones severely pruned.

\section{Effects of Varying Degrees of Dormant Pruning Upon Orchards Just Attaining Bearing Age.}

The Grimes Golden and Lupton orchards were used in this test. The variety was York Imperial in each instance. The trees in the Grimes Golden orchard were seven years old at the beginning of the test and were arranged five in a plot, while the Lupton orchard was six years old with ten trees in a plot. The former orchard was making good growth and the latter only a fair growth at the beginning of the experiment; but both carried too many scaffold limbs which, because of crowding, had made a long but weak growth. An attempt was made to correct this trouble in the experimental plots and in all blocks some large limbs were removed at the start.

Character of Annual Terminal Growth and Weight of Wood Removed. The terminal growth following pruning responded in the same manner as did that in the younger orchards; that is, the heavier pruned trees produced longer and heavier shoots than did those lightly pruned.

TABLE XII.-Character of Annual Terminal Growth and Weight of Wood Removed.

\begin{tabular}{|c|c|c|c|c|c|c|}
\hline & \multicolumn{3}{|c|}{ Grimes Golden Orchard } & \multicolumn{3}{|c|}{ Lupton Orchard } \\
\hline & $\begin{array}{c}\text { Heavy } \\
\text { Pruning }\end{array}$ & $\begin{array}{l}\text { Moderate } \\
\text { Pruning }\end{array}$ & $\begin{array}{l}\text { Light } \\
\text { Pruning }\end{array}$ & $\begin{array}{l}\text { Heavy } \\
\text { Pruning }\end{array}$ & $\begin{array}{l}\text { Moderate } \\
\text { Pruning }\end{array}$ & $\begin{array}{l}\text { Light } \\
\text { Pruning }\end{array}$ \\
\hline $\begin{array}{l}\text { Length of growth in } \\
\text { inches, } 1911\end{array}$ & 12.41 & 14.42 & 15. & 7.87 & 7.30 & 7.75 \\
\hline $\begin{array}{l}\text { Ave. length of growth } \\
\text { in inches, } 1912-15 \ldots . .\end{array}$ & 14.79 & 12.68 & & 15.87 & 10.74 & $8.3 \bar{T}$ \\
\hline $\begin{array}{l}\text { Diameter of growth in } \\
\text { inches, } 1911\end{array}$ & .214 & .211 & .22 & .159 & .156 & .166 \\
\hline $\begin{array}{l}\text { Ave. diam. of growth } \\
\text { in inches, } 1912-15\end{array}$ & .215 & .18 & .172 & .218 & .181 & .166 \\
\hline $\begin{array}{l}\text { Ave. amt. in pounds of } \\
\text { wood removed,1912-15 }\end{array}$ & 8.37 & 7.81 & 3.78 & 3.87 & 3.39 & 1.31 \\
\hline
\end{tabular}


It will be noticed that in both orchards there is very little difference between the weight of wood removed in the heavily pruned and moderately pruned plots but that there is quite a difference in size of terminal growth following the prunings. This difference is due to the fact that the greater part of this weight is composed of large limbs and the heartwood in these trees has little or no effect upon their life processes. The amount of new wood removed influences the character of growth, and of this a much larger amount was removed from the heavily than from the moderately pruned blocks.

Early Bearing and Fruitfulness. Both orchards in the experiment were old enough to have produced a few fruits when

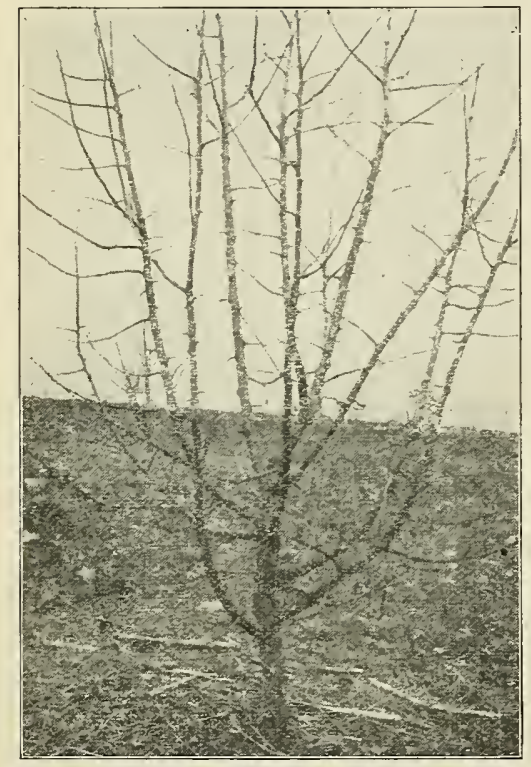

Fig. 16.-Fruit Spurs Formed on Lightly Pruned Stayman Winesap Four Years Old. the experiment was begun in 1912. In the Grimes Golden orchard a few scattering fruits were borne, but as the setting of these was in no wise affected by pruning no account was taken of them the first year. In the Lupton orchard a few blooms appeared in 1912 but no fruit set. In 1913 a late freeze destroyed all fruit set in both orchards, and no record regarding it could be secured. In 1914 and 1915 fruit was secured and the amount produced shed considerable light upon the effect of pruning upon fruit production.

Contrary to the results in the younger orchards, the first crop secured was not strikingly in favor of light pruning. In fact, but little difference was discernible between any of the plots in 1914, light pruning yielding slightly the more in one orchard and moderate pruning leading by a narrow margin in the other. Both orchards were at an age when active bearing should have begun and undoubtedly the entire loss of the 1913 crop had a decided influence on the formation of fruit buds for 1914. It is not only possible but quite probable that the loss of this crop exerted a greater influence upon fruit bud formation than did the different $d$, 
grees of pruning. In 1915 the crops in the two orchards showed marked uniformity in behavior and in each case the heavier pruned plots yielded less than the lighter pruned plots. The combined yields of both years indicate that light pruning is closely correlated with increased fruitfulness. In Table $\mathrm{XV}$, for ease in comparison, yields are shown in terms of percentage, the weight of the yields by the heavily pruned trees being taken as 100 .

TABLE XIII.-Crops in 1914 and 1915. (Lupton Orchard.)

\begin{tabular}{|c|c|c|c|c|c|c|c|}
\hline \multirow[b]{2}{*}{ Type of Pruning } & \multirow[b]{2}{*}{ YeaI } & \multicolumn{2}{|c|}{ Apples 21/4" and up } & \multicolumn{2}{|c|}{ Apples O"-21/4" } & \multirow{2}{*}{$\begin{array}{c}\text { Total } \\
\text { No. } \\
\text { Per } \\
\text { Tree }\end{array}$} & \multirow{2}{*}{$\begin{array}{l}\text { Total Wht. } \\
\text { of Apples } \\
\text { Per Tree } \\
\text { in lbs. }\end{array}$} \\
\hline & & $\begin{array}{l}\text { No. Per } \\
\text { Tree }\end{array}$ & $\begin{array}{l}\text { Wt. Per } \\
\text { Tree in lbs. }\end{array}$ & $\begin{array}{c}\text { No.Per } \\
\text { Tree }\end{array}$ & $\begin{array}{l}\text { Wt. per } \\
\text { Tree } \\
\text { in lbs. }\end{array}$ & & \\
\hline Heavy pruning .... & 1914 & 11.7 & 3.47 & .6 & .04 & 12.3 & 3.51 \\
\hline Moderate pruning... & 1914 & 12.2 & 3.82 & .6 & .06 & 12.8 & 3.88 \\
\hline Light pruning ......... & 1914 & 9. & 2.77 & .77 & .08 & 9.77 & 2.85 \\
\hline Heavy pruning ...... & 1915 & 11.9 & 4.07 & .7 & .14 & 12.6 & 4.21 \\
\hline Moderate pruning.... & 1915 & 22.9 & 6.98 & 3.9 & .53 & 26.8 & 7.51 \\
\hline Light pruning ............ & 1915 & 47.25 & 13.43 & 9.62 & 1.25 & 56.87 & 14.68 \\
\hline Heavy pruning ........ & Aver- & 11.8 & 3.77 & .65 & .09 & 12.45 & 3.86 \\
\hline Moderate pruning... & age, & 17.55 & 5.4 & 2.25 & .3 & 19.8 & 5.7 \\
\hline Light pruning & $\begin{array}{l}\text { both } \\
\text { years }\end{array}$ & 28.12 & 8.1 & 5.2 & .66 & 33.22 & 8.76 \\
\hline
\end{tabular}

TABLE XIV.-Crops in 1914 and 1915. (Grimes Golden Orchard.)

\begin{tabular}{|c|c|c|c|c|c|c|c|}
\hline \multirow[b]{2}{*}{ Type of Pruning } & \multirow[b]{2}{*}{ Year } & \multicolumn{2}{|c|}{ Apples $21 / 4 "$ and up } & \multicolumn{2}{|c|}{ Apples O"-21," } & \multirow{2}{*}{$\begin{array}{c}\text { TotaI } \\
\text { No. } \\
\text { Per } \\
\text { Tree }\end{array}$} & \multirow{2}{*}{$\begin{array}{l}\text { Total Wt. } \\
\text { of Apples } \\
\text { Per Tree } \\
\text { in lbs. }\end{array}$} \\
\hline & & $\begin{array}{l}\text { No. Per } \\
\text { Tree }\end{array}$ & $\begin{array}{c}\text { Wt. Per } \\
\text { Tree in lbs. }\end{array}$ & $\begin{array}{c}\text { No.Per } \\
\text { Tree }\end{array}$ & $\begin{array}{l}\text { Wt. Per } \\
\text { Tree in } \\
\text { lbs. }\end{array}$ & & \\
\hline Heavy pruning ......... & 1914 & 476.2 & 132.7 & 55.4 & 8.9 & 529.6 & 141.6 \\
\hline Moderate pruning.... & 1914 & 378.2 & 106.3 & 45. & 6.5 & 423.2 & 112.8 \\
\hline Light pruning ......... & 1914 & 464.4 & 142.8 & 24. & 3.6 & 488.4 & 146.4 \\
\hline Heavy pruning & 1915 & 163.6 & 63.77 & 4.2 & .57 & 167.6 & 64.34 \\
\hline Moderate pruning... & 1915 & 386.6 & 147.94 & 18.6 & 2.64 & 405.2 & 150.58 \\
\hline Light pruning ... & 1915 & 437.4 & 148.22 & 17.6 & 2.33 & 455 & 150.55 \\
\hline Heavy pruning .... & Aver- & 319.8 & 98.24 & 29.8 & 4.73 & 348.6 & 102.97 \\
\hline Moderate pruning & age, & 382.4 & 127.12 & 31.8 & 4.57 & 414.2 & 131.69 \\
\hline Light pruning ... & $\begin{array}{l}\text { both } \\
\text { years }\end{array}$ & 450.9 & 145.51 & 20.8 & 2.97 & 471.7 & 148.48 \\
\hline
\end{tabular}


TABLE XV.-Yields in 1914 and 1915 in Percentages.

LUPTON ORCHARD.

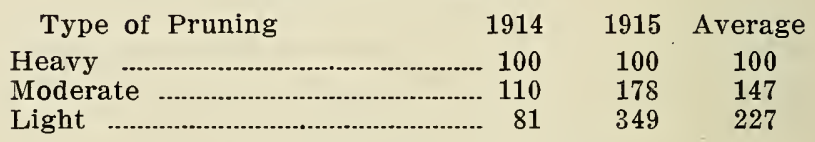

GRIMES GOLDEN ORCHARD.

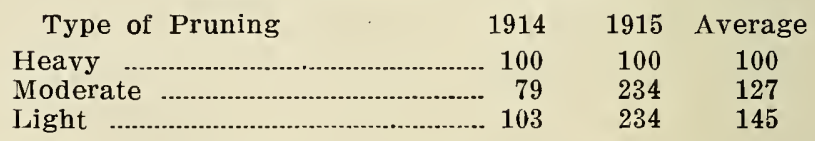

\section{Effects of Varying Degrees of Dormant Pruning upon Bearing Orchards.}

The work in the Boyer orchard was designed to show the effects of pruning upon the vigor and productiveness of trees well launched in their bearing period. As mentioned in the general description of the orchard, the trees were in only a fair condition of vigor at the beginning of the test, but were not in need of what is generally called rejuvenation.

Character of Annual Terminal Growth. The terminal growth in this instance behaved in much the same manner as in the younger orchards. There can be no possibility for doubting that heavy pruning produces rank terminal shoots which give the appearance, at least, of strong vigor. No growth measurements were made in this orchard or in the Grimes Golden and Lupton orchards other than to get the average length and thickness of the main terminal extensions. It was thought at the beginning of the experiment that this would make a fair index of tree growth, but the authors know that such is not the case with young trees at any rate for in the Berkeley Springs orchard the lightly pruned trees with comparatively short terminals produced greater total growth. With the present knowledge it can only be surmised that it may also prove a poor index of vigor for bearing trees. These growth measurements together with records of wood annually removed are set forth in Table XVI.

The large amount of wood removed from the heavily pruned Arkansas block is partly due to a few broken limbs that were removed. The Arkansas block responded much more actively to pruning than did the York Imperial block.

Fruit Production. In the production of fruit, conclusions must be based upon, two crops of Arkansas and one heavy 


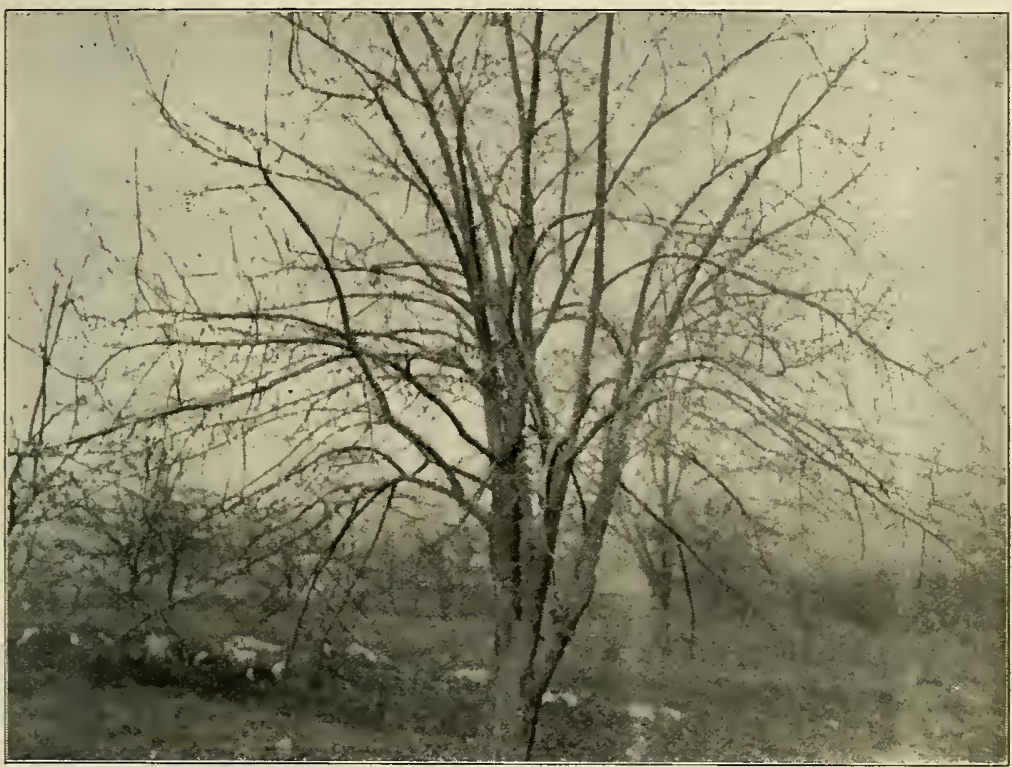

Fig. 17.-Arkansas Tree Before Pruning at the Beginning of the Experiment.

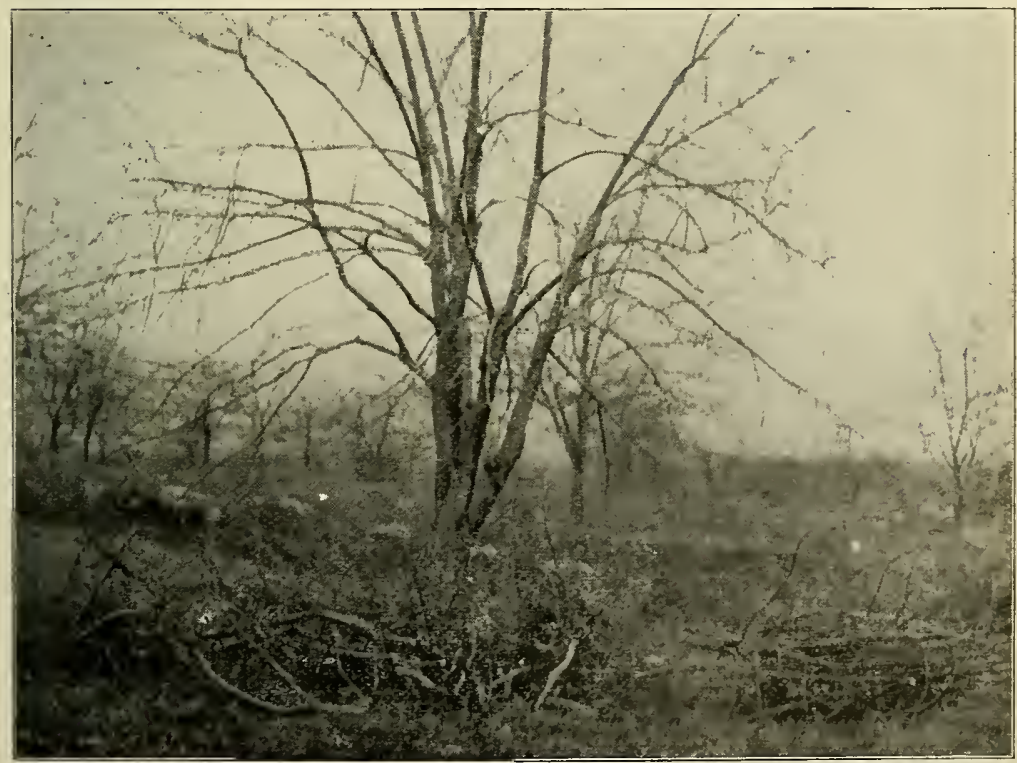

Fig. 18.-Same Tree as Shown in Fig. 17 After Receiving Heavy Dormant Pruning at the Beginning of the Experiment. 
TABLE XVI.-Character of Annual Terminal Growth and Amount of Wood Removed.

\begin{tabular}{|c|c|c|c|c|c|c|}
\hline & \multicolumn{3}{|c|}{ Arkansas } & \multicolumn{3}{|c|}{ York Imperial } \\
\hline & $\begin{array}{c}\text { Heavy } \\
\text { Pruning }\end{array}$ & $\begin{array}{l}\text { Moder- } \\
\text { ate } \\
\text { Pruning }\end{array}$ & $\begin{array}{l}\text { Light } \\
\text { Pruning }\end{array}$ & $\begin{array}{c}\text { Heavy } \\
\text { Pruning }\end{array}$ & $\begin{array}{l}\text { Moder. } \\
\text { ate } \\
\text { Pruning }\end{array}$ & $\begin{array}{l}\text { Light } \\
\text { Pruning }\end{array}$ \\
\hline $\begin{array}{l}\text { Length in inches, } 1911 \\
\text { growth }\end{array}$ & 4.08 & 4.06 & 4.21 & 4.06 & 3.92 & 4.69 \\
\hline $\begin{array}{l}\text { Average growth in inches, } \\
1912-15\end{array}$ & 9.17 & 8.5 & 7.1 & 5.2 & 4.92 & 4.09 \\
\hline $\begin{array}{l}\text { Diameter in inches, } 1911 \\
\text { growth }\end{array}$ & .156 & .149 & .158 & .153 & .152 & .174 \\
\hline $\begin{array}{l}\text { Ave. diameter in inches, } \\
1912-15 \text { growth }\end{array}$ & .189 & .181 & .17 & .137 & .126 & .128 \\
\hline $\begin{array}{l}\text { Wood per tree annually } \\
\text { removed in lbs. 1912-15.. }\end{array}$ & 21.79 & 8.33 & 5.26 & 8.89 & 8.28 & 5.46 \\
\hline
\end{tabular}

crop of York Imperial. The latter variety fruited so heavily in 1914 that it produced no fruit at all the following year. As previously mentioned the freeze in 1913 destroyed all the crop in the region of this experiment, and while a light crop badly affected with cedar rust was borne in 1912 no records regarding it were taken since its formation was not affected by the pruning of that year. The yields as recorded in Table XVII show some interesting departures from those of the younger orchards.

TABLE XVII.-Yields of Fruit (Boyer Orchard).

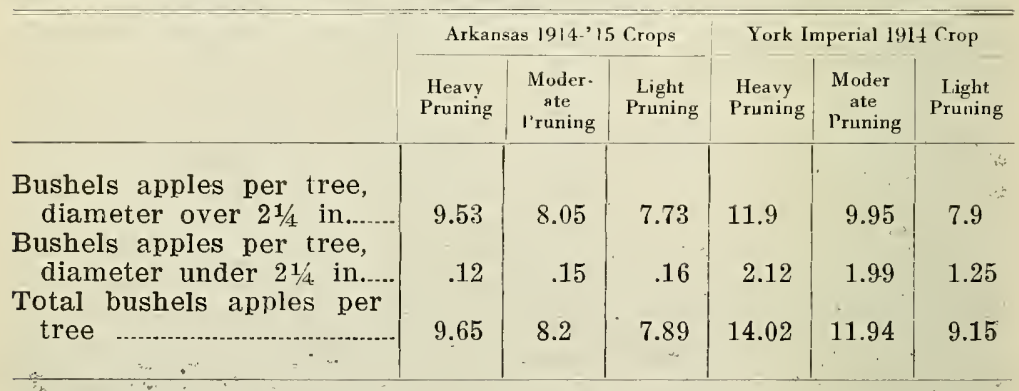

In this case we have an exact reversal of fruiting habits from those in the younger trees. Both the Arkansas and the York Imperial varieties produced distinctly larger crops on the heavily pruned blocks than on the lightly pruned blocks. This sharp distinction in bearing habits between vigorous young trees and middle-aged trees of subnormal vigor is of interest. ("Middle-aged" is only a relative term. In New York where apples are still in their prime at thirty-five years of age, fifteen-year-old trees would be considered young. In 
the Shenandoah valley the commercial orchards generally start their decline at twenty-five to thirty years of age and fifteen to twenty years is truly a middle age.) We know that neglected orchards which have not produced crops of any consequence for years will frequently be greatly benefited and stimulated into fruit production by a heavy pruning. To be sure such trees are abnormal, but it will be noticed that the trees in this orchard made but four inches of terminal growth the year before the experiment began, and that since that time they have averaged from seven to nine inches for one variety and from four to five for the other. This result would indicate that at the beginning the trees were somewhat below normal in vigor, but under better cultural methods their average condition had improved. The writers are of the opinion that, from the standpoint of fruit production, vigorously growing trees would have made a somewhat different response to the treatment than did the ones in the test.

\section{PART II.-The Effects of Seasonal Pruning upon the Growth and Fruitfulness of Trees of Different Ages.}

It is surprising when reviewing the literature on this subject to find how few careful experiments have ever been carried on from which to base our ideas and teachings of the value of summer pruning. The experimental data which we do have lack unity and the results are often contradictory. Batchelor and Goodspeed* of Utah in their summary of a recent publication entitled "The Summer Pruning of a Young Bearing Apple Orchard" have the following to say regarding the summer pruning:

"Trees pruned during dormant period and also during the summer produced a greater annual twig growth than trees pruned during the dormant season only.

"Rubbing the water shoots out of the center of the tree from time to time during the summer had little or no influence on crop production. These shoots are removed more readily and cheaply, however, during this season.

"The summer pruned trees averaged less marketable fruit per tree than either the winter pruned or unpruned trees.

"Summer pruning in this orchard has proven neither profitable nor successful in increasing crop yields.

*Batchelor, L. D. and Goodspeed, W. E., Utah Exp. Sta. Bul1. 140, 1915. 
"Although the investigation is only in its first stages there seems to be a correlation between regular bearing and summer pruning.

"Summer pruning throughout a period of two months between the third week in June and the third week in August produced much the same results."

Vincent ${ }^{1}$ in Idaho found that the average yields for the first four crops of trees given annual summer pruning only were greatly increased in the case of some varieties, while with others this increase was slight and there was very little difference between the yields of summer and winter pruned trees. Wagener showed 111 percent increase in yield where summer pruned, Grimes 52.8 percent, Jonathan 2.4 percent, and Rome 1.6 percent. Color of fruit was much better from the summer pruned trees.

Drinkard ${ }^{2}$ working with dwarf trees in Virginia found that, although summer pruning in the latter part of June checked wood growth, fruit bud formation was greatly stimulated by the practice.

Dickens $^{3}$, in Kansas, by summer pruning was able to make ten-year-old apple trees bear satisfactory crops. Prior to the summer pruning these trees had borne very little.

Papers on "The Summer Pruning of Fruit Trees" by fruit growers and horticulturists of the Royal Horticultural Society $^{4}$ in England showed that, while there was a difference of opinion as to the value of summer pruning, as a whole the consensus of opinion was that summer pruning was uncertain in its effects and that the operation was of doubtful practicability. Much depended on soil, climate, moisture, varieties, stocks, and tine of the operations.

Opinions of 166 fruit growers and gardeners in the British Isles, compiled by the Gardener's Chronicle" show that while 140 had from fair to very good results from summer pruning of pome fruits, 26 were doubtful of its practicability and value.

Spencer Pickering ${ }^{6}$ of the Woburn Experimental Farm, England, reported in Science Progress that, although the evidence was still inconclusive, ordinary annual summer pruning had caused no appreciable results in fruiting or vigor of the apple and that pinching, bending, etc., were uncertain and depended on weather conditions following the operations.

1 Vincent, C. C., Idaho Agr. Exp. Sta., Bull. 84, p. 25, 1915.

1 Vincent, C. C., Rept. Proc. Fruit Products Congress, Spokane, Wash., Nov. $16-21,1914$, pp. 5-6.

2 Drinkard, A. W., Virginia Agr. Exp. Sta., Tech. Bull. 5, pp. 111-12, 1915.

3 Dickens, A., Kansas Sta. Agr. Exp. Sta., Bull. 136, 1906.

* The Journal Royal Horticultural Society, Vol. 33, Part 2, pp. 487-499, 1908.

5 The Gardener's Chronicle, Third Series, Vol. 41, pp. 400-403; 406-7, 1907.

o Science Progress, Vol. 7, No. 27, p. 397, 1913. 
It can be seen from the preceding statements that the results from summer pruning are not always similar. Several different factors, such as the vigor of the tree, the time of pruning, the character of the pruning, the season, the soil, and many others enter in to influence the results.

It is doubtful if any very general recommendations can ever be made regarding summer pruning and although the attthors realize that criticisms can be made on their work, it is presented with the hope that it will add a little more definite information on this subject.

\section{Outline and Plans of the West Virginia Experiments.}

Summer pruning alone and in combination with winter pruning was carried on in all of the orchards previously described, except the Berkeley Springs orchard. Table I shows the various combinations that were used.

The character of the summer pruning only was about the same as was that of the moderate dormant pruning, the only difference being the date on which it was done. The character of the summer pruning has been described on page seven. In the case of the winter and summer pruning, the trees were headed back in the winter and about one-half of the wood was thinned out. In the summer time, the other half of the wood was thinned out and the suckers were remored. In the case of the repeated summer pruning it was attempted to do about the same amonnt of pruning at each date. The sum of these two prunings made about the same as the moderate dormant pruning and left the trees pruned in about the same manner as regards shape, etc. Dates at which these prunings were made are shown on page seven.

\section{The Effects of Seasonal Pruning upon the First Five Years' Growth of Trees.}

Data on this phase of the work were secured entirely from the Sheets orchard. As suggested on page four, conditions in this orchard were not as uniform as we wished to have them. It was necessary to discard several of the original trees due to differences in their ages, and as a result of this only twentythree trees were left in the experiment. The varieties of York Imperial, Grimes, and Rome were included in this test. In as much as all of the varieties responded similarly, the results have been grouped for comparison in the following tables. The summer pruning on these trees was done each year during the first week of July. Varying degrees of dormant pruning were done as previously described. Very little yearly data were secured on these trees with the exception of that of the 
past year, as the main object was to note the effect of the pruning upon fruitfulness.

Character of the Annual Terminal Growth and Amount of Wood Removed. In order to get some data regarding the effect of several years' annual seasonal pruning upon terminal growth, several measurements were made upon all the trees at the close of the growth in 1915. The experiment had then been running for five years.

\section{TABLE XVIII.-Average Length of Terminal Growth and Weight of Wood Removed per Tree.}

\begin{tabular}{|c|c|c|c|c|c|c|}
\hline \multirow[b]{2}{*}{ Method of Pruning } & \multirow{2}{*}{$\begin{array}{c}\text { No. } \\
\text { of } \\
\text { Trees }\end{array}$} & \multirow{2}{*}{$\begin{array}{c}\text { Av. Length } \\
\text { of Terminal } \\
\text { Growth in } \\
\text { Inches } \\
1915\end{array}$} & \multicolumn{4}{|c|}{ Weight Removed in Lbs. per Tree } \\
\hline & & & 1913 & 1914 & 1915 & $\begin{array}{c}\text { Three-Year } \\
\text { Average }\end{array}$ \\
\hline Heavy dormant ........... & 7 & 23.5 & 2.57 & 2.26 & 1.36 & 2.06 \\
\hline Moderate dormant ............... & 5 & 13.5 & 2.25 & 1.6 & .68 & 1.51 \\
\hline Light dormant ......................... & 6 & 9.9 & 1.46 & 1.5 & .54 & 1.17 \\
\hline Summer pruning ................... & 5 & 13.1 & 3.6 & 2.45 & 2.1 & 2.71 \\
\hline
\end{tabular}

These results show that the trees pruned heavily in the dormant season made by far the longest average terminal growth. The summer pruned trees made a longer growth than the trees pruned lightly in the dormant season, but did not make quite as much growth as did the moderately pruned trees.

It is seen that the three-year average weight of wood removed per tree was largest in the case of the summer pruned trees. This, however, is not a very exact or fair comparison as a large amount of this weight was made up of leaves. The actual pruning of the trees was about comparable to that of the moderately pruned ones.

Total Length of Annual Growth. In 1915 the total length of new longitudinal growth produced on all of the trees was measured. These measurements give us some idea of the vigor of the trees and are an indication of the volume of new wood produced.

\section{TABLE XIX.-Average Length per Tree of Longitudinal Growth in 1915.}

Heavy Moderate Light Summer Dormant Dormant Dormant Pruning

Total longitudinal growth produced in feet.

216 187 188 120

Table XIX shows that summer pruning has checked decidedly the growth of the trees as regards total'amount of new wood produced. 
Circumference of Trunks and Size and Form of Trees. Although Table XVIII and Table XIX show that summer pruning has checked the growth of the trees as far as terminal and total annual growths are concerned, it is interesting to know what effect the summer pruning had upon the stockiness of the trees, and their size, and form. Measurements regarding these points were taken on all the trees in 1915.

\section{TABLE XX.-Circumference of Trunks and Height and Width of Trees.}

\begin{tabular}{|c|c|c|c|c|}
\hline Method of Pruning & $\begin{array}{l}\text { No. of } \\
\text { Trees }\end{array}$ & $\begin{array}{l}\text { Circumference } \\
\text { of Trunks in } \\
\text { 1nches }\end{array}$ & $\begin{array}{l}\text { Av. Height } \\
\text { of Tree } \\
\text { in Feet }\end{array}$ & $\begin{array}{l}\text { Av. Width } \\
\text { of Tree } \\
\text { in Feet }\end{array}$ \\
\hline Heavy dormant ........................... & 7 & 8.46 & 8.55 & 4.83 \\
\hline Moderate dormant ..................... & 5 & 9.62 & 9.73 & 6.17 \\
\hline 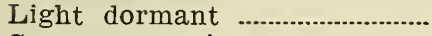 & 6 & 9.91 & 10.5 & 7.1 \\
\hline Summer pruning & 5 & 9.2 & 9.7 & 6.3 \\
\hline
\end{tabular}

It can be seen from Table XX that the trees pruned moderately or lightly during the dormant season have larger trunks than do the summer pruned ones. In the case of the continued heavy dormant pruning, which method we do not recommend, the trunks are smaller than those of the summer pruned trees. As regards the height and width of the trees, it can be seen that the summer pruned trees are very similar to the moderate dormant pruned trees in this respect. The summer pruned trees are larger than the heavy dormant pruned ones, but smaller than the light dormant pruned trees.

Early Bearing. From Tables XVIII, XIX, and XX it can be seen that the summer pruned trees made nearly as long average terminal growths as the moderate dormant pruned ones, but that the total amount of longitudinal growth was less and that the trunks of the trees were smaller. The height and width of the trees were about the same in these two cases. It is interesting now to know what influence summer pruning has had upon early bearing. Although only a few fruits have been produced up to this time, blooming data have been secured each year and also the percentage of fruit buds for 1916.

TABLE XXI.-Effect of Pruning upon Early Bearing.

\begin{tabular}{|c|c|c|c|c|c|c|}
\hline \multirow[b]{2}{*}{ Method of Pruning } & \multirow{2}{*}{$\begin{array}{l}\text { Bloom } \\
\text { Clusters per } \\
\text { Tree in } \\
1914\end{array}$} & \multirow{2}{*}{$\begin{array}{l}\text { Fruits } \\
\text { per Tree } \\
\text { in } 1914\end{array}$} & \multirow{2}{*}{$\begin{array}{l}\text { Bloom } \\
\text { Clusters per } \\
\text { Tree in } \\
1915\end{array}$} & \multicolumn{2}{|c|}{ Fruits per Tree in 1915} & \multirow{2}{*}{$\begin{array}{c}\text { Percent } \\
\text { Fruit Buds } \\
\text { per Tree } \\
1916\end{array}$} \\
\hline & & & & Number & Wt. (lbs) & \\
\hline Heavy dormant ....... & .14 & 0 & 1.86 & .7 & .25 & 3.7 \\
\hline Moderate dormant.. & 3.4 & .2 & 40. & 12.2 & 3.35 & 20.0 \\
\hline Light dormant ......... & 15.5 & 2.0 & 175. & 24. & 6.64 & 38.0 \\
\hline Summer pruning .... & 0 & 0 & 39. & .33 & .08 & 10.4 \\
\hline
\end{tabular}


Table XXI shows that the light dormant pruning caused the trees to come into bearing earlier and to produce considerably more fruit than did any of the other methods of pruning. The summer pruned trees did not bear as early nor dicl they produce as much fruit in 1914 and 1915 as did any of the modifications of dormant pruning. The percentage of fruit buds set for the 1916 crop on the moderate and light dormant pruned trees greatly exceeds that for the summer pruned trees. In this experiment, summer pruning has checked tree growth and has delayed and decreased fruit production.

\section{Effects of Seasonal Pruning upon Orchards Just Attaining Bearing Age.}

Information upon this phase of the work was secured from the Lupton and Grimes Golden orchards. The variety used in each of these orchards was the York Imperial. Fortyfive trees of five each in a plot were used in the Grimes Golden orchard, while there were ninety trees of ten in a plot in the

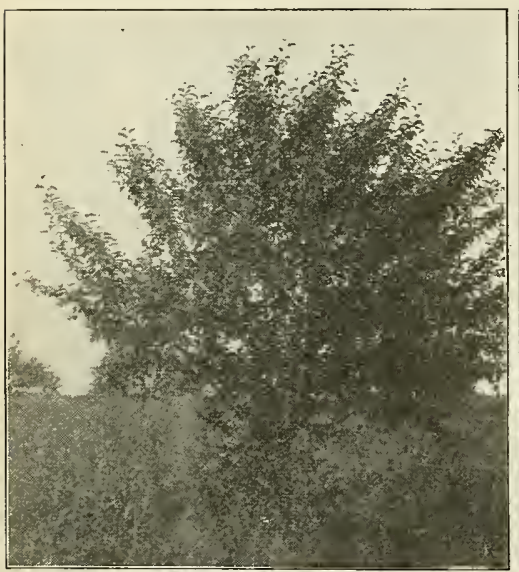

Fig. 19.--York Imperial Tree in Lupton Orchard Before Summer Pruning.

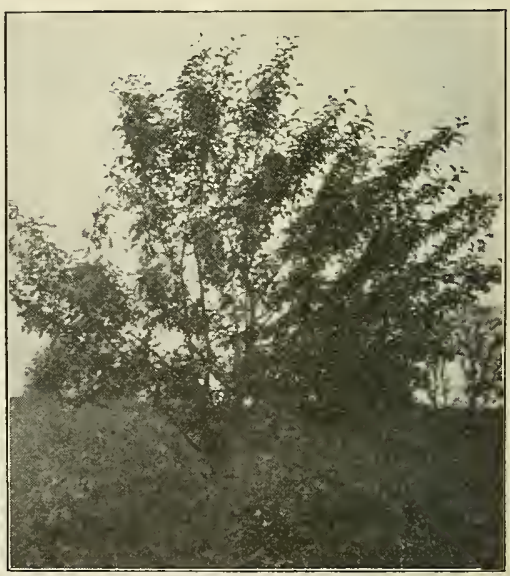

Fig. 20.--Same Tree as Shown in Fig. 19 After Summer Pruning.

Lupton orchard. It was necessary for various reasons to discard certain trees from each orchard during the experiment and as a result there were left 37 trees in the Grimes Golden orchard and 88 in the Lupton orchard which are here reported on. Trees in the Grimes Golden orchard were seven years old at the beginning of the experiment, while those in the Lupton orchard were six. In these orchards varying degrees of dor- 
mant pruning, dormant and summer pruning, and summer pruning only were carried on.

By referring to Table I and to the discussion under "Definition of Treatment" on page seven, a fuller explanation of the experiments can be found.

Character of Annual Terminal Growth and Weight of Wood Removed. The length and diameter of the terminal growth* of each tree in the experiment were taken in the spring of 1911, in order to show the condition of the trees at the beginning of the experiment. These measurements have been continued each year until the present time and the averages for the years 1912 to 1915 inclusive are shown in the accompanying table. The amount of wood removed at each pruning has been weighed and the weights are likewise shown.

\section{TABLE XXII.-Character of Annual Terminal Growth and Weight of Wood Removed (Lupton Orchard).}

\begin{tabular}{|c|c|c|c|c|c|}
\hline \multirow{2}{*}{ Method of Pruning } & \multicolumn{2}{|c|}{$\begin{array}{l}\text { Average Length of } \\
\text { Terminal Growth. }\end{array}$} & \multicolumn{2}{|c|}{$\begin{array}{l}\text { Average Diameter of } \\
\text { of Terminal Growth }\end{array}$} & \multirow{2}{*}{$\begin{array}{l}\text { Weight of Wood } \\
\text { Removed in } \\
\text { lbs; } \\
1912 \cdot 15\end{array}$} \\
\hline & 1911 & $1912-15$ & 1911 & $1912-15$ & \\
\hline Heavy dormant & 7.87 & 15.87 & .159 & .218 & 3.87 \\
\hline Moderate dormant & 7.30 & 10.74 & .156 & .181 & 3.39 \\
\hline Light dormant & 7.75 & 8.37 & .166 & .166 & 1.31 \\
\hline $\begin{array}{l}\text { Heavy dormant and } \\
\text { early summer }\end{array}$ & 8.65 & 15.99 & .172 & .212 & 4.83 \\
\hline $\begin{array}{l}\text { Moderate dormant and } \\
\text { early summer }\end{array}$ & 8.50 & 13.45 & .18 & .193 & 8.50 \\
\hline Early summer only....... & 8.29 & 10.48 & .174 & .177 & 7.05 \\
\hline Midsummer only ............ & 7.31 & 8.83 & .17 & .17 & 5.87 \\
\hline Repeated summer & 7.78 & 8.55 & .172 & .167 & 6.32 \\
\hline Ringing ........ & $\begin{array}{l}(1918) \\
9.86\end{array}$ & $\left|\begin{array}{c}(1914-15) \\
6.63\end{array}\right|$ & .174 & .157 & 4.69 \\
\hline
\end{tabular}

A study of Table XXII shows that in the Lupton orchard where early summer pruning has been used in connection with heavy and moderate dormant pruning (plots four and five), the length and diameter of the terminal growth have been slightly increased over plots one and two where no summer pruning was used. However, this slight increase may well be due to chance, as it will be noticed that where early summer pruning alone was used (plot six) the resulting terminal growth was neither as long nor as thick as was that restlting where only the moderate or heavy dormant pruning was used. Neither was this beneficial effect noted in the Grimes Golden orchard. 
In the plots where midsummer or repeated summer prunings were given, both the length and thickness of the resulting terminal growths were considerably reduced. Ringing also had a decidedly detrimental effect upon the resultiny growth.

TABLE XXIII,-Character of Annual Terminal Growth and Weight of Wood Removed (Grimes Golden Orchard).

\begin{tabular}{|c|c|c|c|c|c|}
\hline \multirow{2}{*}{ Method of Pruning } & \multicolumn{2}{|c|}{$\begin{array}{l}\text { Average Length of } \\
\text { Terminal Growth }\end{array}$} & \multicolumn{2}{|c|}{$\begin{array}{c}\text { Average Diameter of } \\
\text { Terminal Growth }\end{array}$} & \multirow{2}{*}{$\begin{array}{l}\text { Weight of Wood } \\
\text { Removed in lbs. } \\
1912-15\end{array}$} \\
\hline & 1911 & 1912-'15 & 1911 & 1912-'15 & \\
\hline Heavy dormant ................ & 12.41 & 14.79 & .214 & .215 & 8.37 \\
\hline Moderate dormant ......... & 14.42 & 12.68 & .211 & .18 & 7.81 \\
\hline Light "dormant .................. & 15. & 11.36 & .22 & .172 & 3.78 \\
\hline Heavy dormant and & & & & & \\
\hline early summer .............. & 1.4 .5 & 13.62 & .214 & .205 & 17.09 \\
\hline $\begin{array}{l}\text { Moderate dormant and } \\
\text { early summer }\end{array}$ & 13.26 & 10.71 & 199 & .162 & 7.68 \\
\hline Early summer only......... & 14.72 & 12.18 & .214 & .182 & 10.59 \\
\hline Midsummer only ............. & 13.59 & 11.31 & .202 & .169 & 11.36 \\
\hline Repeated summer ........... & 14.91 & 11.56 & .219 & .174 & 12.01 \\
\hline Ringing & 16.96 & 9.95 & .212 & .152 & 9.54 \\
\hline
\end{tabular}

In the Grimes Golden orchard (Table XXIII) heavy or moderate dormant pruning caused a larger terminal growth than any of the other treatments. In this case, the early summer pruning, instead of being beneficial when used in connection with the heavy and moderate dormant pruning, seemed to be detrimental. In this orchard as in the Lupton orchard, early summer pruning alone was not as beneficial as either the heavy or moderate dormant pruning when used alone. Although the midsummer and repeated summer pruning did not appear to retard the terminal growth as much in this orchard as in the Lupton orchard, still they noticeably retarded growth when compared to dormant pruning only. Ringing in this orchard seriously affected terminal growth as it did in the Lupton orchard.

Although trees pruned in the summer appear to have had more weight removed than did the dormant pruned ones, a large proportion of this weight was leaves. The summer pruning, as previously stated, was about the same in amount and degree as the moderate dormant pruning.

Increase in Trunk Circumference. At the close of the 1914 season the circumference of the tree trunks half way between the head and the ground was measured on each tree in the Grimes Golden orchard. These same trees were measured 
at the close of the 1915 season in order to find if the seasonal pruning had exerted any influence on the increase in trunk measurement.

\section{TABLE XXIV.-Increase in One Year in Circumference of Trunks Due to Seasonal Pruning.}

Method of Pruning

Heavy dormant

Moderate dormant

Light dormant

Heavy dormant and early summer

Moderate dormant and early summer.

Early summer

Midsummer

Repeated summer

Ringing
Increase in Trunk Circumference in Inches

2.2

2.15

2.15

2.

2.

2.2

1.95

1.88

1.95

The results show that midsummer and repeated summer pruning retard the growth of the tree trunks in much the same way as they did the terminal growth.

When early summer pruning was used in connection with heavy and moderate dormant pruning, the increase in trunk was not as large as in those cases where the dormant pruning was used alone. This is similar to the effects produced on terminal growth as shown in Tables XXII and XXIII. When used alone early summer pruning gave satisfactory increase.

Effect of Seasonal Pruning on Size of Leaves, Color of Foliage, and Total Amount of Foliage. Differences in foliage were so plainly noticeable in the different pruning plots at picking time (October, 1915) that careful measurements and counts were made of the leaves on the different trees in the several plots. In securing the length and width of the leaves, fifty were selected from each tree and measured. These measurements for all trees in each block were then averaged and the results taken as the average size of leaves for that block. The area of the leaf was found by multiplying the length by seven-tenths of the width. In finding the total number of leaves per tree, one tree was taken as representing the ideal in size and denseness of foliage and considered as 100 in size and number of leaves. The total number of leaves on this tree was then counted for use as a basis in comparing the other trees. All of the remaining trees were then compared to the ideal tree in size and in number of leaves and given a certain percentage rating. By comparing these percentages to the ideal we were able to get quite accurately the total number of leaves per tree. The total number of leaves found for all trees in each plot was then averaged to find the average $11 \mathrm{um}-$ 
ber of leaves per tree in each plot. By multiplying the average number of leaves per tree by the average area per leaf, the total average area of leaf surface per tree in each plot was obtained.

TABLE XXV.-Size of Leaves and Total Area of Leaves per Tree as Affected by Seasonal Pruning (Lupton Orchard).

\begin{tabular}{|c|c|c|c|c|c|c|}
\hline Method ol Pruning & $\begin{array}{l}\text { Ave. Length } \\
\text { of Leaves } \\
\text { in Inches }\end{array}$ & $\begin{array}{l}\text { Ave. Width } \\
\text { of Leaves } \\
\text { in Inehes }\end{array}$ & $\begin{array}{c}\text { Area of } \\
\text { Leaves in } \\
\text { Sq. Inches }\end{array}$ & $\begin{array}{l}\text { Total No. } \\
\text { of Leaves } \\
\text { Per Tree }\end{array}$ & $\begin{array}{l}\text { Total Area } \\
\text { per Tree } \\
\text { Sq. Fi. }\end{array}$ & Rank \\
\hline Heavy dormant ...... & 2.60 & 1.52 & 2.77 & 31,755 & 610.8 & 1 \\
\hline Moderate dormant ... & 2.46 & 1.38 & 2.37 & 26,263 & 432.2 & 4 \\
\hline Light dormant........... & 2.3 & 1.3 & 2.1 & 28,718 & 418.7 & 5 \\
\hline $\begin{array}{l}\text { Heavy dormant and } \\
\text { early summer }\end{array}$ & 2.48 & 1.54 & 2.67 & 28,290 & 524.5 & 2 \\
\hline $\begin{array}{l}\text { Mod. dormant and } \\
\text { early summer }\end{array}$ & 2.29 & 1.33 & 2.13 & 30,473 & 450.7 & 3 \\
\hline Early summer ......... & 2.34 & 1.39 & 2.28 & 24,253 & 384. & 6 \\
\hline Midsummer & 2.36 & 1.32 & 2.18 & 18,760 & 284. & 9 \\
\hline Repeated summer.... & 2.28 & 1.3 & 2.07 & 20,689 & 297.4 & 8 \\
\hline Ringing .................. & 2.26 & 1.27 & 1.91 & 24,588 & 325.4 & 7 \\
\hline
\end{tabular}

TABLE XXVI.-Size of Leaves and Total Area of Leaves per Tree as Affected by Seasonal Pruning (Grimes Golden Orchard).

\begin{tabular}{|c|c|c|c|c|c|c|}
\hline Method of Pruning & $\begin{array}{l}\text { Ave. Length } \\
\text { of Leaves } \\
\text { in Inches }\end{array}$ & $\begin{array}{l}\text { Ave. Width } \\
\text { of Leaves } \\
\text { in Inches }\end{array}$ & $\begin{array}{l}\text { Area of } \\
\text { Leaves in } \\
\text { Sq Inches }\end{array}$ & $\begin{array}{l}\text { Total No. } \\
\text { of Leaves } \\
\text { per Tree }\end{array}$ & $\begin{array}{l}\text { Tolal Area } \\
\text { per Tree } \\
\text { Sq. Ft. }\end{array}$ & Rank \\
\hline Heavy dormant......... & 3.57 & 2.0 & 4.99 & 36,309 & 1143.8 & 1 \\
\hline Moderate dormant .. & 3.51 & 1.7 & 4.18 & 31,403 & 911.5 & 2 \\
\hline Light dormant........... & 3.1 & 1.62 & 3.52 & 26,987 & 659.6 & 4 \\
\hline Heavy dormant and & & & & & & \\
\hline early summer........ & 3.23 & 1.69 & 3.82 & 29,931 & 794.0 & 3 \\
\hline Mod. dormant and & & & & & & \\
\hline early summer........ & 3.17 & 1.7 & 3.77 & 20,117 & 526.6 & 6 \\
\hline Early summer ........... & 2.73 & 1.6 & 3.06 & 21,589 & 458.7 & 8 \\
\hline Midsummer & 2.8 & 1.47 & 2.88 & 24,042 & 480.8 & 7 \\
\hline Repeated summer.... & 2.54 & 1.36 & 2.42 & 17,787 & 298.9 & 9 \\
\hline Ringing & 2.94 & 1.64 & 3.38 & 23,061 & 541.2 & 5 \\
\hline
\end{tabular}

Tables XXV and XXVI give-in tabular form the size of leaves per tree, total number of leaves per tree, total leaf area per tree, and the rank of each plot based upon the total leaf area per tree. It is plainly noticeable that the trees pruned during the dormant season had by far the larger leaves and the greater number of leaves. In contrast to this the trees 
which had been summer pruned only produced the smaller leaves and ranked lower regarding total number of leaves and area of foliage. Early summer pruning in connection with dormant pruning retarded leaf development somewhat and when used alone did not produce as good results as did the moderate dormant pruning. These results are similar to those found in Tables XXII, XXIII, and XXIV where its effects on terminal growth and trunk increase were noted. It will be noticed that, although the first five plots in each orchard vary a little in their order of rank, they all place ahead of early summer pruning. The next three plots of summer pruning all fall in the lowest ranks.

Color of Foliage. Differences in color of the foliage were likewise very noticeable at this date (October) but earlier in the season no striking differences were discernible. In all cases those trees which had been pruned during the dormant season or with some modification of the dormant season pruning had a darker green and healthier looking foliage. The leaves of the midsummer and repeated summer pruned trees had turned a yellowish green color and presented a much less vigorous appearance.

It is impossible to explain definitely these striking differences in foliage. We know that the leaves, under the action of chlorophyll, transform the raw materials, brought them from the roots, into plant food. It is also understood that some of this plant food is then stored in the main branches and smaller twigs where the tree can draw upon it in the future. By summer pruning not only are large numbers of these active leaves removed but probably much stored food in the limbs and twigs is also removed. It is very probable that by destroying many of the manufacturing parts of the plant and removing some stored up food that these effects will be noticed in the reduced leaf area the following year.

The change in color of the foliage is still harder to explain. It may be that due to the weaker condition of the summer pruned trees, as evidenced by lessened terminal growths, small tree trunks, less foliage, etc., the leaves of the summer pruned trees had passed through their cycle of activity earlier than the leaves on the dormant pruned, more healthy trees. These activities were probably followed by a breaking down of the chlorophyll which would be reflected by a diminishing of the dark green color.*

Early Bearing and Fruitfulness. Having seen that summer pruning has acted as a check on the growth and develop-

\footnotetext{
*In future investigations on this subject it would be highly advantageous to make quantitative determinations of the chlorophyll present in the leaves.
} 
ment of young trees just coming into bearing, let us see what effect summer pruning has had upon the first crop of such trees. As stated on page twenty-four, there were a few blooms on each orchard in 1912, following the year that the experiment was begun. As the setting of these was not affected by pruning and since so few of them did set, no account of them was taken. Unfortunately, a late freeze in 1913 destroyed all fruit set in both orchards, so no record of the crop could be secured in that year. However, in 1914 and 1915 there was fruit in both orchards and some interesting data were secured concerning the effects of seasonal pruning on the first crop of young orchards.

TABLE XXVII.-Crop in 1914 (Lupton Orchard).

\begin{tabular}{|c|c|c|c|c|c|c|}
\hline \multirow[b]{2}{*}{ Method ol Pruaing } & \multicolumn{2}{|c|}{ Apples $21 / 4 "$ and $U_{p}$} & \multicolumn{2}{|c|}{ Apples 0.21/" } & \multirow{2}{*}{$\begin{array}{c}\text { Total } \\
\text { Number } \\
\text { per } \\
\text { Tree }\end{array}$} & \multirow{2}{*}{$\begin{array}{c}\text { Total Wt. } \\
\text { of Apples } \\
\text { per Tree } \\
\text { in lbs. }\end{array}$} \\
\hline & $\begin{array}{l}\text { No. per } \\
\text { Tree }\end{array}$ & $\begin{array}{l}\text { Wt. per } \\
\text { Tree, lbs. }\end{array}$ & $\begin{array}{c}\mathrm{N}_{0} \text {, per } \\
\text { Tree }\end{array}$ & $\begin{array}{l}\text { Wt. per } \\
\text { Tree, Ibs. }\end{array}$ & & \\
\hline Heavy dormant ...... & 11.7 & 3.47 & .6 & .04 & 12.3 & 3.51 \\
\hline Moderate dormant & 12.2 & 3.82 & .6 & .06 & 12.8 & 3.88 \\
\hline Light dormant ............. & 9. & 2.77 & .77 & .08 & 9.77 & 2.85 \\
\hline $\begin{array}{l}\text { Heavy dormant and } \\
\text { early summer }\end{array}$ & 2.4 & .77 & .3 & .03 & 2.7 & .81 \\
\hline $\begin{array}{l}\text { Mod. dormant and } \\
\text { early summer }\end{array}$ & 15.4 & 5.45 & 1.1 & .12 & 17.5 & 5.57 \\
\hline Early summer & 11.6 & 3.62 & .9 & .11 & 12.5 & 3.73 \\
\hline Midsummer & 5.4 & 1.73 & .5 & .06 & 5.9 & 1.79 \\
\hline Repeated summer ...... & 5.9 & 2.15 & .3 & .03 & 6.2 & 2.18 \\
\hline Ringing & 62.5 & 17.56 & 7.25 & 1.00 & 69.75 & 18.56 \\
\hline
\end{tabular}

TABLE XXVIII,-Crop in 1915 (Lupton Orchard).

\begin{tabular}{|c|c|c|c|c|c|c|}
\hline \multirow[b]{2}{*}{ Method ol Pruning } & \multicolumn{2}{|c|}{ Apples $2 \frac{1}{4}$ " and up } & \multicolumn{2}{|c|}{ Apples $0.2^{1 / 4}$} & \multirow{2}{*}{$\begin{array}{c}\text { Toial } \\
\text { Number } \\
\text { per Tree }\end{array}$} & \multirow{2}{*}{$\begin{array}{l}\text { Total Wt. } \\
\text { of Apples } \\
\text { per Tree } \\
\text { in lbs, }\end{array}$} \\
\hline & $\begin{array}{l}\mathrm{N}_{0 .} \text { per } \\
\text { Tree }\end{array}$ & $\begin{array}{l}\text { Wi. per } \\
\text { Tree, lbs. }\end{array}$ & $\begin{array}{l}\text { No. per } \\
\text { Tree }\end{array}$ & $\begin{array}{c}\text { Wt. per } \\
\text { Tree. lbs. }\end{array}$ & & \\
\hline Heavy dormant ..... & 11.9 & 4.07 & .7 & .14 & 12.6 & 4.21 \\
\hline Moderate dormant .... & 22.9 & 6.98 & 3.9 & .53 & 26.8 & 7.51 \\
\hline Light dormant .............. & 47.25 & 13.43 & 9.62 & 1.25 & 56.87 & 14.68 \\
\hline $\begin{array}{l}\text { Heavy dormant and } \\
\text { early summer ........... }\end{array}$ & 5.7 & 1.76 & .7 & .08 & 6.4 & 1.84 \\
\hline $\begin{array}{l}\text { Mod. dormant and } \\
\text { early summer }\end{array}$ & 24.6 & 7.51 & 3.4 & .54 & 28.0 & 8.05 \\
\hline Early summer & 20.3 & 6.06 & 3.3 & .47 & 23.6 & 6.53 \\
\hline Midsummer & 10.3 & 3.36 & 1.3 & .16 & 11.6 & 3.52 \\
\hline Repeated summer & 11.5 & 3.24 & 2.4 & .29 & 13.9 & 3.53 \\
\hline 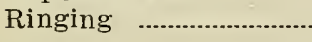 & 1.6 & .56 & .4 & $\cdot .05$ & 2.0 & .61 \\
\hline
\end{tabular}


TABLE XXIX.-Average Crops in 1914 and 1915 (Lupton Orchard).

\begin{tabular}{|c|c|c|c|c|c|c|}
\hline \multirow[b]{2}{*}{ Method ol Pruning } & \multicolumn{2}{|c|}{ Apples $21 / 4 "$ and up } & \multicolumn{2}{|c|}{ Apples $0-21 / 4$} & \multirow{2}{*}{$\begin{array}{c}\text { Total } \\
\text { Number } \\
\text { per } \\
\text { Tree }\end{array}$} & \multirow{2}{*}{$\begin{array}{l}\text { Total Wl, } \\
\text { ol Apples } \\
\text { per Tree } \\
\text { in lbs. }\end{array}$} \\
\hline & $\begin{array}{l}\text { No, per } \\
\text { Tree }\end{array}$ & $\begin{array}{l}\text { Wt. per } \\
\text { Tree, Ibs. }\end{array}$ & $\underset{\text { Tree }}{N_{0 . \text { per }}}$ & $\begin{array}{l}\text { Wi. per } \\
\text { Tree, lbs. }\end{array}$ & & \\
\hline Heavy dormant ..... & 11.8 & 3.77 & .65 & .09 & 12.45 & 3.86 \\
\hline Moderate dormant & 17.55 & 5.4 & 2.25 & .3 & 19.8 & 5.7 \\
\hline Light dormant ........... & 28.12 & 8.1 & 5.19 & .66 & 33.32 & 8.76 \\
\hline Heavy dormant and & & & & & & \\
\hline early summer & 4.05 & 1.26 & .5 & .05 & 4.55 & 1.32 \\
\hline early summer & 20.5 & 6.48 & 2.25 & .33 & 22.75 & 6.81 \\
\hline 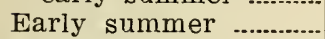 & 15.95 & 4.84 & 2.1 & .29 & 18.05 & 5.18 \\
\hline Midsummer & 7.85 & 2.54 & .9 & .11 & 8.75 & 2.61 \\
\hline Repeated summer & 8.7 & 2.69 & 1.35 & .16 & 10.05 & 2.85 \\
\hline 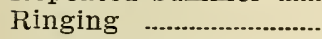 & 32.05 & 9.06 & 3.82 & .52 & 35.87 & 9.58 \\
\hline
\end{tabular}

TABLE XXX.-Crop in 1914 (Grimes Golden Orchard).

\begin{tabular}{|c|c|c|c|c|c|c|}
\hline \multirow[b]{2}{*}{ Method ol Pruning } & \multicolumn{2}{|c|}{ Apples $21 \% "$ and up } & \multicolumn{2}{|c|}{ Apples $0-21 / 4 "$} & \multirow{2}{*}{$\begin{array}{l}\text { Total } \\
\text { Number } \\
\text { Apples per } \\
\text { Tree }\end{array}$} & \multirow{2}{*}{$\begin{array}{c}\text { Total Wt } \\
\text { ol Apples } \\
\text { per Tree } \\
\text { in lbs. }\end{array}$} \\
\hline & $\underset{\text { Tree }}{\mathrm{N}_{\text {o. per }}}$ & $\begin{array}{l}\text { Wr. per } \\
\text { Tree, lbs. }\end{array}$ & $\begin{array}{c}\text { No. per } \\
\text { Tree }\end{array}$ & $\begin{array}{l}\text { Wt, per } \\
\text { Tree, lbs. }\end{array}$ & & \\
\hline Heavy dormant ........... & 476.2 & 132.7 & 55.4 & 8.9 & 529.6 & 141.6 \\
\hline Moderate dormant .... & 378.2 & 106.3 & 45. & 6.5 & 423.2 & 112.8 \\
\hline Light dormant ............. & 464.4 & 142.8 & 24. & 3.6 & 488.4 & 146.4 \\
\hline $\begin{array}{l}\text { Heavy dormant and } \\
\text { early summer }\end{array}$ & 46.0 & 18.5 & 8. & 1.12 & 54. & 19.62 \\
\hline $\begin{array}{l}\text { Mod. dormant and } \\
\text { early summer }\end{array}$ & 228.5 & 77.5 & 9.5 & 1.25 & 238.0 & 78.75 \\
\hline Early summer ............. & 76.6 & 28.3 & 2. & .52 & 78.6 & 28.82 \\
\hline Midsummer .................. & 13.0 & 4.4 & 1.8 & .2 & 14.8 & 4.6 \\
\hline Repeated summer ...... & 38.5 & 16.0 & .75 & .09 & 39.25 & 16.09 \\
\hline Ringing & 661.4 & 150.4 & 150.6 & 18.20 & 812.0 & 168.6 \\
\hline
\end{tabular}

TABLE XXXI.-Crop in 1915 (Grimes Golden Orchard).

\begin{tabular}{|c|c|c|c|c|c|c|}
\hline \multirow{2}{*}{ Method of Pruning } & \multicolumn{2}{|c|}{ Apples 21/4" and up } & \multicolumn{2}{|c|}{ Apples $0 \cdot 2 \frac{1}{4}{ }^{\prime \prime}$} & \multirow{2}{*}{$\begin{array}{c}\text { Total } \\
\text { Number } \\
\text { Apples per } \\
\text { Tree }\end{array}$} & \multirow{2}{*}{$\begin{array}{l}\text { Total Wt. } \\
\text { of Apples } \\
\text { per Tree } \\
\text { in lbs. }\end{array}$} \\
\hline & $\begin{array}{c}\text { No. per } \\
\text { Tree }\end{array}$ & $\begin{array}{l}\text { Wt. per } \\
\text { Tree, lbs. }\end{array}$ & $\begin{array}{c}\text { No.per } \\
\text { Tree }\end{array}$ & $\begin{array}{l}\text { Wi. per } \\
\text { Tree, lbs. }\end{array}$ & & \\
\hline Heavy dormant ........ & 163.4 & 63.77 & 4.2 & .57 & 167.6 & 64.34 \\
\hline Moderate dormant ... & 386.6 & 147.94 & 18.6 & 2.64 & 405.2 & 150.58 \\
\hline Light dormant ........... & 437.4 & 148.22 & 17.6 & 2.33 & 455.0 & 150.55 \\
\hline $\begin{array}{l}\text { Heavy dormant and } \\
\text { early summer .......... }\end{array}$ & 334.0 & 97.50 & 0.0 & 0.0 & 334. & 97.50 \\
\hline $\begin{array}{l}\text { Mod. dormant and } \\
\text { early súmmer }\end{array}$ & 265.5 & 69.74 & 18.5 & 2.09 & 284. & 71.83 \\
\hline Early summer .............. & 222.4 & 66.02 & 22.6 & 3.39 & 245 . & 69.41 \\
\hline Midsummer ................... & 236.0 & 58.34 & 44.6 & 6.19 & 284.6 & 64.53 \\
\hline Repeated summer ....... & 211.25 & 59.34 & 22.25 & 3.68 & 233.5 & 63.02 \\
\hline Ringing & 0.0 & 0.0 & 0.0 & 0.0 & 0.0 & 0.0 \\
\hline
\end{tabular}


TABLE XXXII.-Average Crops in 1914 and 1915. (Grimes Golden Orchard).

\begin{tabular}{|c|c|c|c|c|c|c|}
\hline \multirow[b]{2}{*}{ Method of Pruning } & \multicolumn{2}{|c|}{ Apples $2 \frac{1}{4} "$ and up } & \multicolumn{2}{|c|}{ Apples $0.2 \frac{1}{4} "$} & \multirow{2}{*}{$\begin{array}{c}\text { Total } \\
\text { Number } \\
\text { Apples per } \\
\text { Tree. }\end{array}$} & \multirow{2}{*}{$\begin{array}{l}\text { Total Wt. } \\
\text { of Apples } \\
\text { per Tree } \\
\text { in lbs. }\end{array}$} \\
\hline & $\begin{array}{l}\text { No. per } \\
\text { Tree }\end{array}$ & $\begin{array}{l}\text { Wi. per } \\
\text { Tree lbs. }\end{array}$ & $\begin{array}{c}\text { No. per } \\
\text { Tree }\end{array}$ & $\begin{array}{l}\text { Wl. per } \\
\text { Tree. Jbs. }\end{array}$ & & \\
\hline Heavy dormant ..... & 319.8 & 98.24 & 29.8 & 4.73 & 348.60 & 102.97 \\
\hline Moderate dormant & 382.4 & 127.12 & 31.8 & 4.57 & 414.2 & 131.69 \\
\hline Light dormant ............ & 450.9 & 145.51 & 20.8 & 2.96 & 471.7 & 148.48 \\
\hline $\begin{array}{l}\text { Heavy dormant and } \\
\text { early summer }\end{array}$ & 190. & 58.00 & 4.0 & .56 & 194.0 & 58.56 \\
\hline $\begin{array}{l}\text { Mod. dormant and } \\
\text { early summer ........ }\end{array}$ & 247. & 73.62 & 14.0 & 1.67 & 261.0 & 75.29 \\
\hline Early summer ......... & 149.5 & 47.16 & 12.3 & 1.95 & 161.8 & 48.96 \\
\hline Midsummer .............. & 124.5 & 31.37 & 25.20 & 3.19 & 149.7 & 34.57 \\
\hline Repeated summer .. & 124.87 & 37.67 & 11.5 & 1.88 & 136.37 & 39.55 \\
\hline Ringing & 330.7 & 75.20 & 75.30 & 9.10 & 403.00 & 84.30 \\
\hline
\end{tabular}

Although the 1914 crop in the Lupton orchard was very light (Table XXVII) still the results were uniform enough to indicate the effect of seasonal pruning on fruitfulness. It will be seen in this case that the dormant pruned trees yielded about twice as much fruit as those trees pruned in midsummer, or repeated summer. The early summer pruning alone seemed to give satisfactory results, but in connection with dormant pruning its effects were rather contradictory. The following year, the trees under the different pruning methods responded in practically the same manner as they had the previous year. Table XXVIII shows that the yield of fruit from the dormant pruned trees far exceeded that from the summer pruned ones. In Table XXIX the yields for the two crops in the Lupton orchard have been averaged and recorded. A study of this table emphasizes the points just brought out. Midsummer or repeated summer pruning has seriously retarded crop production. Early summer pruning, while evi: dently not as detrimental as the later prunings, does not produce as satisfactory results as moderate or light dormant pruning.

In the Grimes Golden orchard, where larger crops were produced, practically the same results were obtained as in the Lupton orchard. Tables XXX and XXXI show the yields from the different plots in 1914 and 1915, while Table XXXII gives the average yields for these two years. In this table, it will be seen that the average weight of fruit from the dormant pruned plots was 127.71 pounds per tree; from the dormant and early summer pruned plot, 66.92 pounds per tree; 
and from the summer pruned plots, 41.02 pounds per tree. In both orchards the light dormant pruning gare the best results as regards fruit production.

For ease in comparison, the yields of the dormant pruned trees, the dormant and summer pruned trees, and the ones pruned in the summer time only have been averaged for each orchard, and are shown in terms of percentages. The weight of fruit from the dormant pruned trees is taken as 100 .

TABLE XXXIII.-YYields of 1914 and 1915 in Percentages.

LUPTON ORCHARD.

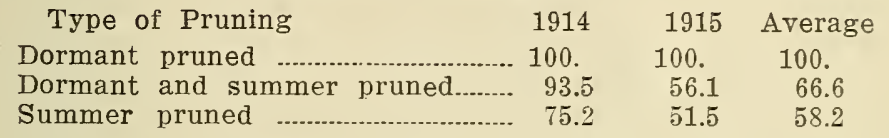

GRIMES GOLDEN ORCHARD.

\begin{tabular}{|c|c|c|c|}
\hline Type of Pruning & 1914 & 1915 & Average \\
\hline Dormant pruned ... & 100 & 100. & 100. \\
\hline Dormant and $\mathrm{s}$ & 36.8 & 69.5 & 52 \\
\hline Summer pruned & 12.3 & 53.9 & 32.1 \\
\hline
\end{tabular}

These results are very similar to those found by Batchelor and Goodspeed in $L^{-} \operatorname{tah}^{1}$. These authors, in reporting the results of four years' pruning experiments on young bearing Jonathan trees, state that the summer pruned plots averaged 191 pounds of fruit less per tree for the four years than did similar trees pruned in the dormant season. The summer pruned plots also averaged 112 pounds of fruit less per tree than the unpruned trees. Their reports on similarly prunerl Gano trees show that the summer pruned trees produced 112 pounds per tree less than the dormant pruned ones and 219 pounds per tree less than unpruned trees.

Our experiments on young trees bearing their first crops thus show that summer pruning has reduced both vigor and fruitfulness.

\section{The Effects of Ringing on the Growth and Fruitfulness of Young Apple Trees.}

On May 31, 1913, seven trees in the Lupton orchard and five in the Grimes Golden orchard were ringed. At that time, the foliage was well developed and the sap was flowing freely. These trees were pruned at the time of ringing in 1913 and received a light to moderate pruning before growth started

* Batchelor, L. D. and Goodspeed, W. E., Utah Agr. Exp. Sta., Bull, 110. 
in 1914 and 1915. In the operation of ringing a small circular band of bark extending through the cortex and bast about three-fourths of an inch in width was removed from each tree at about four inches above the level of the ground. Theoretically, ringing is not supposed to prevent the passage of the unassimilated sap from the roots to the leaves, but does prevent the distribution of the assimilated sap below the place ringed. By causing this large amount of food material to be stored in the upper parts of the tree, the formation of many more fruit buds is supposed to take place. With a view of obtaining some data as to the effects of ringing on the vigor and fruitfulness of young bearing apple trees, this experiment was started.

Effect of Ringing on Terminal Growth. By referring to Table XXII and Table XXIII the effect of ringing on the terminal growth in the two orchards can be seen. It will be noticed in both orchards that the terminal growth was as vigorous as any at the beginning of the experiment. The ringing seriously retarded this growth in the next two years. In both orchards the ringed trees made a poorer terminal growth than did any of the other plots. In the Lupton orchard, the terminal growth on the heavy dormant pruned trees was more than twice as vigorous as that on the ringed trees. Ringing in this case certainly reduced the vigor of the trees.

Effect of Ringing on Trunk Circumference. The increase in trunk circumference in the Grimes Golden orchard was taken for the year 1914. In Table XXIV it will be seen that the ringing acted as a check in trunk development when compared with the dormant pruning. The trunks of the ringed trees increased at the same rate as did those pruned in midsummer.

Effect of Ringing on Size of Leaves and Total Area of Leaf Surface. By referring to Tables XXV and XXVI the effect of ringing on foliage development can be seen. In the case of the ringed trees in the Lupton orchard, the leaves were shorter and narrower and had less area than did those in any of the other plots. These trees had slightly more leaves per tree than did the summer pruned ones, but considerably fewer than the dormant pruned trees. The ringed plot ranked seventh as regards total leaf area per tree. In the case of the Grimes Golden orchard, ringing again acted as a check to leaf development. Although in this case the leaves were slightly larger than those on the summer pruned tree, still they were considerably smaller than those on the dormant 
pruned trees. This weakened appearance of the tree as regards color and amount of foliage was very plainly noticeable. In fact, the trees appeared more sickly than the figures show.

Effect of Ringing on Fruitfulness. Tables XXVII to XXIX show the effect of ringing on fruitfulness in the Lupton orchard. It will be seen that in 1914, the year following the ringing, the ringed trees bore larger amounts of fruit than did those in any of the other plots. However, the following year, 1915, these same trees bore practically no fruit, while the other plots produced good crops.

Similar results were secured in the Grimes Golden orchard only in a more striking degree. Tables XXX to XXXII show that while the ringed trees bore the largest crops in 1914, they produced no fruit whatever in 1915. It will also be noticed that the apples were undersized and poor in 1914. It should be noted here that the season of 1914 was very dry. This may partially account for the lack of development of the fruit of that year and for the depleted tree vigor that was so apparent. Although the ringed trees in both orchards have appeared to regain their vigor somewhat during the present year (1916) still they are far from being as vigorous as the dormant pruned trees and are bearing practically no fruit buds. Three trees ringed in this orchard in 1912 responded in the same manner as those just described. All bore well in 1913 but produced practically nothing in 1914 and 1915.

From the results of our observations, ringing plainly checks the vigor of the tree for at least three years and although it has been successful in causing trees to bear the year following the operation, this bearing has not been established as a habit.

Experiments on Ringing Apples in Other States. Howe of the Geneva New York Station" in his summary on "Ringing Fruit Trees" states that under certain conditions ringing may induce and possibly increase fruitfulness in apples, but it rarely has these favorable effects on other fruits. He also states that only young and very vigorous apple trees, possibly now and then pear and cherry trees, can survive ringing and that even with these fruits the compensating gains seldom offset the injury to the trees. He found that the general effect of ringing on the roots of the trees was to decrease their size and number and lessen their vigor.

Drinkard in Virginia ${ }^{2}$ working with young dwarf apples concluded that ringing at different seasons when accompanied

1 Howe, G. H., N. Y. Agr. Exp. Sta., Bull. 391.

a Drinkard, A. W. Jr., Va. Agr. Exp. Sta., Tech. Bull. 5. 
or preceded by spring pruning of the branches produced no noticeable stimulation of fruit bud development, but that when ringing was done at the time the foliage was fully developed in the absence of spring pruning, fruit bud development was uniformly increased. In this case, although the growth of the trees was good, he states that the foliage of the trees was somewhat sparse, about fifty or sixty percent of that of the check trees:

Maynard in Massachusetts ${ }^{1}$ found that although ringing or girdling crab-apple trees increased fruitfulness, he considered that the practice should be applied only under special conditions.

The Geneva New York Station ${ }^{2}$ found the practice of ringing to be devitalizing also when applied to other plants such as the tomato, grape, and chrysanthemum.

\section{Effects of Seasonal Pruning upon Bearing Orchards.}

Data as to the effects of seasonal pruning upon bearing orchards were secured from the Boyer orchard. Seventy trees consisting of fourteen rows, five in each row of the Arkansas (Mammoth Black Twig) and York Imperial varieties, fifteen years old at the beginning of the experiment, were used in this test. Five trees of one variety were used in each plot. An outline of the experiment and a general description of the orchard can be found on pages five and seven under the heading "Outline of the West Virginia Experiments." This orchard at the beginning of the experiment was not in a very vigorous condition but under the influence of clean cultivation, leguminous cover crops, and some fertilization it soon became vigorous and healthy.

Character of Annual Terminal Growth. The length and diameter of the terminal growth was measured each year in the different plots as it was thought that they would be a good index of the vigor of the trees. The amount of wood removed each year was also weighed and records were kept.

1 Mass. Hatcll Agr. Exp. Sta., Bull. $1: 12-13$.

2 Hedrick, U. P., Taylor, O. M., and Wellington, Richard, N. Y., Agr. Exp. Sta., Bull. 288.

2 Paddock, Wendell, N. Y. Agr. Exp: Sta., Bull. 151. 
TABLE XXXIV.-Character of Annual Terminal Growth and Amount of Wood Removed (Arkansas).

\begin{tabular}{|c|c|c|c|c|c|}
\hline Method of Pruning & $\begin{array}{l}\text { Length in } \\
\text { Inches } \\
1911\end{array}$ & $\begin{array}{l}\text { Average } \\
\text { Length in } \\
\text { Inches } \\
1912 \text { - }^{-15}\end{array}$ & $\begin{array}{l}\text { Diameter } \\
\text { in Inches } \\
1911\end{array}$ & $\begin{array}{l}\text { Average } \\
\text { Diameter } \\
\text { in Inches } \\
1912-15\end{array}$ & $\begin{array}{l}\text { Weight in } \\
\text { Ibs. } \\
\text { Removed } \\
\text { per Tree } \\
1912.15\end{array}$ \\
\hline Heavy dormant ........................ & 4.08 & 9.17 & .156 & .189 & 21.79 \\
\hline Moderate dormant ................... & 4.06 & 8.5 & 149 & .181 & 8.33 \\
\hline Light dormant .......................... & 4.21 & 7.1 & .158 & .17 & 5.26 \\
\hline $\begin{array}{l}\text { Heavy dormant and early } \\
\text { summer }\end{array}$ & 4.22 & 8.52 & .158 & .192 & 30.51 \\
\hline $\begin{array}{l}\text { Moderate dormant and } \\
\text { early summer }\end{array}$ & 4.94 & 8.88 & .171 & .187 & 13.87 \\
\hline Early summer & 3.84 & 7.25 & .173 & .169 & 17.66 \\
\hline Midsummer & 4.15 & 8.86 & .171 & .184 & 38.38 \\
\hline
\end{tabular}

TABLE XXXV.-Character of Annual Terminal Growth and Amount of Wood Removed (York Imperial).

\begin{tabular}{|c|c|c|c|c|c|}
\hline Method of Pruning & $\begin{array}{l}\text { Length in } \\
\text { Inches } \\
1911\end{array}$ & $\begin{array}{c}\text { Average } \\
\text { Length in } \\
\text { Inches } \\
1912-15\end{array}$ & $\begin{array}{l}\text { Diameter } \\
\text { in Inches } \\
1911\end{array}$ & $\begin{array}{l}\text { Average } \\
\text { Diameler } \\
\text { in Inches } \\
1912 \text {-15 }^{-15}\end{array}$ & $\begin{array}{l}\text { Weight in } \\
\text { Jbs. } \\
\text { Removed } \\
\text { per Tree } \\
1912-15\end{array}$ \\
\hline Heavy dormant ............ & 4.06 & 5.2 & .153 & .137 & 8.89 \\
\hline Moderate dormant & 3.92 & 4.92 & .152 & .126 & 8.28 \\
\hline 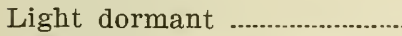 & 4.69 & 4.09 & .174 & .128 & 5.46 \\
\hline $\begin{array}{l}\text { Heavy dormant and early } \\
\text { summer }\end{array}$ & 4.55 & 5.49 & .158 & .14 & 20.38 \\
\hline $\begin{array}{l}\text { Moderate dormant and } \\
\text { eariy summer }\end{array}$ & 5.16 & 5.9 & .16 & .144 & 17.46 \\
\hline Early summer & 4.71 & 4.66 & .165 & .135 & 23.2 \\
\hline Midsummer & 4.85 & 4.37 & .176 & .134 & 12.31 \\
\hline
\end{tabular}

It can be seen in Table XXXIV and Table XXXV that in the case of large bearing trees, pruning at different seasons of the year did not influence the terminal growth as did seasonal pruning on very young trees or trees just bearing their first crops. While with the Arkansas variety heavy dormant pruning caused a slightly longer and thicker terminal growth than did the other treatments, it will be noticed that the terminal growths in the other plots are about the same and that none of these are much below those in the heavy dormant pruned plot. In the case of the York Imperial variety the dormant pruned trees and those trees which had a combination of dormant and early summer pruning seemed to have produced slightly more vigorous growth than did either the early summer or midsummer pruned trees, with the exception of the 
light dormant pruned trees. These trees produced the weakest terminal growths of all plots. Taken as a whole the summer pruning did not seem to check seriously the terminal growth in middle-aged bearing trees. A study of Tables XXXIV and XXXV shows that as far as effect of summer pruning upon terminal growth is concerned, little can be said. With both varieties, midsummer as well as early summer pruning produced a more vigorous growth than that which followed light dormant, but with one exception less vigorous than that produced by moderate or heavy dormant pruning. It is not thought that the vigorous growth of Arkansas following midsummer pruning has any special significance since this does not hold true with the York Imperial and our experience with younger trees indicates quite clearly that midsummer pruning is more devitalizing than early summer pruning. Taken as a whole the data from this orchard indicate that with middle-aged trees summer pruning may be practiced with less danger of seriously retarding growth than in the case of younger trees. The large amount of wood removed from the summer pruned trees can be explained by the fact that a large proportion of this weight was made up of leaves, which additional weight was not encountered in the case of the dormant pruned trees.

Fruit Production. The records which we were able to obtain on fruit production as influenced by seasonal pruning were rather poor, and very little reliance can be placed upon them. In 1912, the year the experiment was started, there was an unusually severe outbreak of cedar rust in the county. This disease checked the development of York Imperial so seriously that no records of the crop were taken that year. It is questionable, however, if the pruning would have had much effect, if any, on the crops the first year. In 1913, a late freeze destroyed all fruit set and yield records were again lost. In 1914 , both varieties yielded well and records of the crops were obtained. In 1915, the Arkansas again developed a good crop, but the York Imperial, being a biennial bearer and having borne heavily in 1914, produced practically no crop. Thus, it can be seen that data were obtained on the yield of Arkansas for two years in succession but that the yield for only one year was obtained on the York Imperial variety.

The different seasonal prunings seemed to produce no uniform effects on these bearing treess. In the case of the Arkansas, while midsummer pruning seemed to produce the greatest yields, early summer pruning on the other hand did not materially increase fruitfulness. Likewise the effects of early summer pruning in connection with heavy and moder- 


\section{TABLE XXXVI.-Yields of Fruit in the Boyer Orchard per Tree (Arkansas).}

Average in Bushels per Tree for 1914 and 1915 Crops.

\begin{tabular}{|c|c|c|c|c|}
\hline Merhod ol Pruning & $\begin{array}{c}\text { Bushels } \\
2^{1}{ }_{4}^{\prime \prime} \text { and up }\end{array}$ & $\begin{array}{l}\text { Bushels, } \\
0.2^{1} t^{\prime \prime}\end{array}$ & $\begin{array}{l}\text { Total Bushels } \\
\text { per Tree }\end{array}$ & Rank \\
\hline Heavy dormant ...................... & 9.53 & .12 & 9.65 & 3 \\
\hline Moderate dormant ............... & 8.05 & .15 & 8.2 & 4 \\
\hline 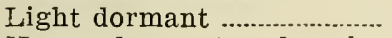 & 7.73 & .16 & 7.89 & 5 \\
\hline $\begin{array}{l}\text { Heavy dormant and early } \\
\text { summer }\end{array}$ & 10.38 & .16 & 10.54 & 2 \\
\hline $\begin{array}{l}\text { Moderate dormant and } \\
\text { early summer }\end{array}$ & 5.56 & .07 & 5.63 & 7 \\
\hline Early summer & 6.51 & .10 & 6.61 & 6 \\
\hline Midsummer & 10.88 & .13 & 11.01 & 1 \\
\hline
\end{tabular}

\section{TABLE XXXVII.-Yields of Fruit in the Boyer Orchard per Tree (York Imperial).}

Average in Bushels per Tree in 1914 Crop.

\begin{tabular}{|c|c|c|c|c|}
\hline Method of Pruning & $\begin{array}{l}\text { Bushels } \\
2^{1}+* \text { and up }\end{array}$ & $\begin{array}{l}\text { Bushels. } \\
0.22_{4} .\end{array}$ & $\begin{array}{l}\text { Total Bushels } \\
\text { per Tree }\end{array}$ & Rank \\
\hline Heavy dormant & 11.9 & 2.12 & 14.02 & 3 \\
\hline Moderate dormant & 9.95 & 1.99 & 11.94 & 5 \\
\hline Light dormant ...................... & 7.9 & 1.25 & 9.15 & 6 \\
\hline $\begin{array}{l}\text { Heavy dormant and early } \\
\text { summer }\end{array}$ & 12.5 & 2.5 & 15.00 & 2 \\
\hline $\begin{array}{l}\text { Moderate dormant and } \\
\text { early summer..................... }\end{array}$ & 12.75 & 1.06 & 13.81 & 4 \\
\hline Early summer & 14.7 & 1.95 & 16.65 & 1 \\
\hline Midsummer & 7.0 & 1.12 & 8.12 & 7 \\
\hline
\end{tabular}

ate dormant pruning were un-uniform and varied. With the York Imperial variety the rank of the different summer prunings was just reversed. In this case, early summer pruning produced the largest yields, while the midsummer pruned trees were the poorest in this respect. Those trees which received both a heary dormant and an early summer pruning yielded well in both varieties and held the same rank. Likewise the heavy dormant pruned trees yielded well and held the same rank in both varieties.

As stated previously too much weight should not be placed on these results as in the one case they represent only one crop and in the other but two. In the case of the middleaged trees seasonal pruning did not exert such marked difference as in younger trees. The heavy and moderate dormant prunings seemed to be very satisfactory and uniform in their results, while the results of the different summer prunings were contradictory and unconvincing. 


\section{CONCLUSION.}

From the work of the West Virginia Agricultural Experiment Station on the pruning of apple trees several general recommendations may be safely made for conditions of growth as they exist in West Virginia. During the first four or five years after a tree is planted its form must be moulded and consequently pruning must be more or less severe during this period. During the first two or three years as much as threefourths of the total length of new growth may be removed annually and the vigor of the tree will not only be unimpaired but apparently increased and at the same time a strong compact head is insured. After this, however, continued severe annual pruning and particularly rigorous heading back will surely dwarf the growth and delay fruit bearing. After the second or third year the pruning should be confined almost entirely to branch thinning with heading back practiced only when necessary to maintain the symmetry of the tree. In a two-story tree where the upper scaffold is not started until the third year heading in must be continued on this scaffold for two or three years to make a satisfactory top, but here it should be discontinued as soon as possible. In short, to secure maximum growth together with early fruting, the pruning during the period from planting to bearing age should be just sufficient to get a well formed head and then to keep the branches properly thinned. In older trees which have been neglected, heavy pruning, both thinning and cutting back to lower the top, may be practiced to stimulate new growth but should be followed in subsequent years only by normal branch thinning. Old trees in good condition should receive light annual thinning of branches.

A great deal has been written and spoken in support of summer pruning but from the experiments already discussed we can only conclude that it is a practice unsuited to West Virginia conditions. In no case did it hasten the fruiting of young trees or increase their crops after they came to a bearing age. On the other hand, it clearly impaired the vigor of the tree. Theoretically, it should check growth and induce fruit bud formation. Unquestionably, it checked growth but the fruit buds failed to follow. 


\section{SUMMARY.}

1. This bulletin is a preliminary report of a pruning experiment covering a period of four years and embracing 366 apple trees of various ages. Study has been made of the effects on vigor and fruitfulness of various degrees of dormant pruning, summer pruning at different times, and combinations of dormant and summer pruning.

2. Heavy annual dormant pruning resulted in stronger terminal growth than lighter pruning on trees of all ages.

3. In the study of trees up to five and six years of age it was found that annual heavy dormant pruning was beneficial from the growth standpoint for the first two or three years after which it dwarfed growth so that by the end of the period the lightly pruned trees showed a strikingly greater increase in trunk diameter, branch diameter, size of top, and total annual growth.

4. With trees five or six years old at the close of the experiment heavy annual dormant pruning delayed fruit bud formation and light pruning encouraged it.

5. With trees of bearing age (six or seven years at beginning of test) heavy annual dormant pruning diminished crop production and light annual dormant pruning increased it.

6. With fifteen-year-old bearing trees in only a fair state of vigor heavy annual dormant pruning increased fruit production.

7. Early, midsummer, and repeated summer pruning, as a rule, impaired tree vigor as evidenced by smaller annual growth, smaller leaf area, and light colored foliage. Early summer pruning was less deterrent in its effect than was repeated or midsummer pruning.

8. There is no evidence to show that either early, repeated, or midsummer pruning will hasten the bearing period of young trees or increase crop production of trees of bearing age.

9. Ringing of trees caused heavy crop production the following season but so impaired the vigor that no crop was produced the second or third year, and at least three seasons were required to restore the tree to normal conditions.

10. With normal trees maximum growth and production will be secured by light annual dormant pruning except with trees under three years of age which will respond more satisfactorily to heavy dormant pruning. 


\section{BIBLIOGRAPHY OF APPLE PRUNING.}

Alderman, W. H., The Results of Apple Pruning Investigations.-Proc. of the Soc. Hort. Sci., Twelfth Annual Meeting (1915), pp. 54-59.

Aldrich, H. A., An Experiment in Pruning Old Trees.-Trans. I11. Sta. Hort. Soc. (1899), pp. 48-54.

Allen, W. J., Pruning.-Agr. Gaz., New South Wales, Vol. 15, No. 8 (1904), pp. 798-800.

Anonymous, Science of Fruit Tree Fruitfulness Simplified.Agr. Jour. Cape Good Hope, Vol. 14, No. 5 (1899), pp. 296-298.

Atwood, W., Kraus, E. J., Lewis, C. I., and Gardner, V. R., Pruning.-Oregon Agr. Col. Exp. Sta., Bulletin 130 (May, 1915).

Baltet, C. \& Charquerand, Principles of Pruning Shrubs.Florists Exchange No. 17, (1899), pp. 470-471.

Balmer, J. A., Pruning Orchard Trees.-Wash. Exp. Sta. Bulletin 25 (1896).

Bailey, L. H., The Pruning Book.-The MacMillan Company, New York, (1898).

Pruning.-The Principles of Fruit Growing.The MacMillan Company, New York, 20th edition, (1915), pp. 230-241.

Batchelor, L. D., Pruning the Apple Orchard.-Utah Exp. Sta., Circular No. 9 (March, 1913).

and Goodspeed, W. E., The Summer Pruning of

a Young Bearing Apple Orchard.-Utah Exp. Sta., Bulletin No. 140 (November, 1915).

Bedford and Pickering, Cultural Experiments on Apples, Etc. -Woburn Exp. Fruit Farm, Fifth Report (1905).

Report (1907).

Bryant, Arthur, Trimming of Trees.-I1l. Sta. Hort. Soc. Report (1902), pp. 251-254.

Bunyard, E. A., The Physiology of Pruning.-Jour. Roy. Hort. Soc. (1909-10), pp. 330-334.

Bunyard, G. and Thomas, O., The Fruit Garden.-Chas. Scribner, publisher, New York (1904).

Bussard, Leon and Duval, G., Arboriculture Fruitiere.-J. B. Bailliere \& Sons, Paris (1907).

Card, F. W., Notes on Pruning.-Nebr. Exp. Sta. Bulletin No. 50 (November, 1897). 
Pruning Trees When Planted (Results of Three Years' Growth), Rhode Island Exp. Sta. Rept. (1901), pp. 238-241.

Pruning Trees When Planted.--Rhode Island Exp. Sta. Report (1898), pp. 107-110.

Pruning at Planting Time--Rhode Island Exp. Sta. Rept. (1907), pp. 264-265.

Chandler, W. H. and Knapp, H. B., Pruning.-Cornell Reading Course, Vol. V, No. 104 (January, 1916), pp. 75-84.

Corbett, L. C., Pruning.-U. S. Dept. of Agr., Farmers' Bulletin 181 (September, 1903).

Tree Pruning.-West Va. Agri. Exp. Sta. Rept. (1896), p. 208.

Crandall, C. S., Pruning.-I11. Sta. Hort. Soc. Rept. (1902), pp. 396-400.

Crider, F. J., Practical Orchard Pruning.--South Carolina Exp. Sta. Bulletin 176 (April, 1914).

Dickens, Albert, Summer Pruning.-Kansas Exp. Sta. Bulletin 136, (1906), p. 181.

Drinkard, A. W. Jr., Some Effects of Pruning, Root Pruning, Ringing and Stripping on the Formation of Fruit Buds on Dwarf Apple Trees.-Va. Exp. Sta. Tech. Bulletin No. 5 (April, 1915).

Editor of Gardeners Chronicle, Summer Pruning.-Gardeners Chronicle, Series 3, Vol. 41, No. 1069 (1907), pp. 400-406.

Editor of Nature, Horticultural Investigations at Woburn.Nature, Vol. 91 (Aug. 29, 1913), pp. 675-678.

Effects of Pruning on Fruit Trees (Woburn Experiments).-Nature, Vol. 75 (April 11, 1907), pp. 569-570.

Funk, J. H., Pruning, Fertilizing and Thinning.-Penn. Sta. Dept. of Agr. Report (1903), pp. 791-796.

Gardner, V. R., A Consideration of the Question of "Bulk" Pruning.-Proc. of Am. Pom. Soc,, Berkeley Meeting (1915), pp. 135-143.

, How Some Current Pruning Practices Defeat the Real Objects of Pruning.-The Apple Annual.-Rept. Proc. Fruit Products Congress, Spokane, Wash. (Nov. 17-22, 1913).

Goethe, R., Die einwirkung des all jahrlich ausgefuhrten schnittes auf das wachstum der baume. (Bericht der Kgl. lehranstalt fur obst.-wein-und Gartenbau zu Geisenheim am Rhein) (1899-1900), pp. 18-21.

Goff, E. S., An Ideal Method of Pruning Fruit Trees.-Am. Gard. Vol. 22, No. 325 (1901), p. 188. 
Gould, H. P., Growing Fruit for Home Use in the Great Plains Area.-U. S. Dept. of Agr., Farmers' Bulletin 727 (1916), pp. 19-27.

Goumy, E., Recherches sur les bourgeoes des arbres fruitiers. -Ann. Sci. Nat. Bot. (Paris) 9e Serie 1 (1905), pp. 135-246.

Hedrick, U. P., Pruning Fruit Trees.-N. Y. Agr. Exp. Sta. Circular No. 13 (January, 1910).

Heaton, J. C. B., Pruning and Its Effects on the Future Health and Life of the Tree.-Ill. Sta. Hort. Soc. Report (1896), pp. 246-248.

Heiges, S. B., Time and Method of Pruning, Report of Pomologist.-U. S. Dept. of Agr., (1895).

Herrick, R. S., Pruning the Commercial Orchard.-Iowa Sta. Hort. Soc. (1913), pp. 175-179.

Hoskins, T. H., Forming the Heads of Fruit Trees.-Garden and Forest, Vol. 7, (July 11, 1894), p. 277.

Some Points in Pruning Fruit Trees.-Garden and Forest Vol. 7, (April 11, 1894), p. 144.

Hoyt, Edwin, Pruning.-Mass. State Hort. Soc. Report (1894), p. 28.

Hutt, W. N., Pruning of Trees and Bush Fruits.- - Etah Exp. Sta. Bulletin 83 (October, 1903).

Ikeda, T., The Training and Pruning of Fruit Trees in Japan. -Jour. Roy. Hort. Soc. (1910-11), pp. 581-586.

Jarvis, C. D., Apple Growing in New England.--Storrs Conn. Exp. Sta. Bulletin 66 (1911), pp. 240-253.

Judson, L. B., Pruning the Apple Orchard.-Idaho Exp. Station Bulletin 47 (February, 1905).

Keffer, C. A., The Early Growth and Training of Apple Trees. Tenn. Exp. Sta. Bulletin, Vol. 14, No. 4 (December, 1901). Training and Pruning Fruit Trees and Vines.Tenn. Exp. Sta. Bulletin, Vol. 17, No. 3 (July, 1904).

Kraus, E. J., Fruit Bud Formation Related to Orchard Practice.-Annual Report of the Washington State Horticultural Association (Nov. 15-17, 1915), pp. 24-29.

Lake, E. R., The Apple in Oregon.-Oregon Sta. Bulletin 82, (November, 1904), pp. 26-37.

Lansdell, J., Pruning Fruit Trees After Planting.-Jour. Roy. Hort. Soc. (1909-10), pp. 384-385.

Lazenby, W. R., Notes on Pruning.-Proc: Soc. Hort. Sci. (1908-9), pp. 27-30. 
Lewis, C. I., Pruning, A Question Requiring a Great Deal of Thought.-Better Fruit Vol. 8, No. 9 (March, 1914), pp. 11-12.

Long, E. A., Extremes in Pruning.-Am. Gard., Vol. 17 (1896), No. 75, p. 340.

Suggestions on Tree Pruning.-Am. Gard., Vol. 17 (1896), No. 65, pp. 180-181.

Lucas, E., Die Lehre vom Baumschnitt fur die deutschen Garten bearbeitet Stuttgart (1909), 8 ed. Rev., pp. 16-334.

Malthouse, G. T., Garden and Orchard.-Harper Adams Agr Col., Newport, Salop and in Staffordshire and Shropshire, Field Experiments Report (1910), p. 52.

Maynard, S. T. and Drew, Geo., Orchard Management, Cover Crops in Orchards, Pruning of Orchards, Report on Fruits. -Mass. Agr. Exp. Sta. Bulletin 82 (1902).

Merrill, F. S., Pruning:-Kansas Exp. Sta. Circular 49 (Mạrch, 1915).

Middleton, T. H., Digest of Pruning Experiments. (The Woburn Experimental Fruit Farm).-Nature, Vol. 72 (Sept. 7, 1905 ), p. 461.

Molyneux, E., Pruning Newly Planted Apple Trees.-Gard. Chron. Vol. 15 (1894), Series 3, pp. 341-342.

Morris, O. M., Pruning.--Wrashington Exp. Sta. Pop. Bulletin 79 (February, 1915).

Munson, W. M., Pruning Notes.-Maine Exp. Sta. Bulletin 139 (1906), pp. 60-64.

Orpet, E. O., Pruning:-Amer. Gard. Vol. 19, No. 193 (1898), p. 619.

Paddock, Wende1l, Pruning Fruit Trees.-Col. Exp. Sta. Bu1letin 106 (December, 1905).

and Whipple, Pruning Young and Mature Trees. -Fruit Growing in Arid Regions, The MacMillan Company, New York, (1914), pp. 80-146.

Pickering, S., Tree Pruning and Manuring.-Hort. Research II Sci. Prog. 20th Century 7 (1913) No. 27, pp. 397-442.

and others, The Summer Pruning of Fruit Trees Jour. Roy. Hort. Soc., Vol. 33 Part 2 (1908), pp. 487-499. Powell, G. H., The Pruning of Young Fruit Trees.-Del. Exp Sta. Bulletin 45, (October, 1899).

Quinn, George, Fruit Tree Pruning.-Jour. Agr. and Ind., South Australia, Vol. 3 (1899), pp. 368-378.

Further Notes on Fruit Growing in Tasmania.

-Jour. Agr. and Ind., South Australia, Vol. 8 (1904), No.

2. pp. 69-78. 
Rane, F. Wm., Notes on Pruning.-W. Va. Agr. Exp. Sta. Bulletin 27 (November, 1892).

Saunders, Wm., Pruning of Trees and Other Plants.-U. S. Dept. of Agr. Year Book (1898), pp. 151-166.

Sears, F. C., Report of Nova Scotia School of Horticulture.Report of Secy. of Agri., Nova Scotia, (1902), p. 87. Pruning-Productive Orcharding.-J. B. Lippincott Co., Philadelphia and London, (1914), pp. 119-141. Standish, J. V. W., Training and Pruning Trees and Shrubs.I11. Sta. Hort. Soc. Rept. (1901), pp. 277-280.

Steigerwalt, W. F., Pruning Fruit Trees.-Iowa Sta. Hort. Soc. (1903), pp. 285-286.

Stuart, W., Apple Culturre in Vermont.-Vt. Exp. Sta. Bulletin 141, pp. 63-100.

Taft, L. R., Physiological Effects of Pruning.-Report Am. Pom. Soc. (1891).

Thornber, W. S., Pruning Fruit Trees.-Wash. Exp. Sta. Pop. Bulletin 3 (1908).

Tower, Gordon E., Pruning and Shaping the Young Apple Tree.-The Apple Annual.-Rept. Proc. Fruit Products Congress, Spokane, Trash., (Nov. 16-21, 1914), pp. 8-10. Tyson, W. H., Pruning Deciduous Fruits.-Cal. Exp. Sta. Rept. (1893-94), pp. 397-400.

Van Houten, George, Pruning.--Iowa Sta. Hort. Soc., Vol. 18 (1883), pp. 580-583.

Vincent, C. C., Pruning Experiment.-Annual Report for year ending June 30, 1915, Idaho Agr. Exp. Sta. Bull. 84 (Nov. $1915)$, p. 25.

Winter versus Summer Pruning.-The Apple Annual.-Rept. Proc. Fruit Products Congress, Spokane, Trash. (Nov. 16-21, 1914), pp. 5-6.

Watts, R. L., Pruning Fruit Trees.-Tenn. Exp. Sta. Bulletin, Vol. 4, No. 1 (January, 1891).

Whipple, O. B., Pruning Mature Fruit Trees.-Col. Exp. Sta. Bulletin 139 (1909).

Whitten, J. C. and Mason J. C., Effects of Summer Pruning.IVestern Fruit Grower (June, 1909.).

Wilkinson, A. E., Proper Pruning The Apple.-Ginn and Co., New York (1915), pp. 83-90.

Woods, Albert F., Principles of Pruning and Care of Wounds in Woody Plants.-U. S. Dept. Agr. Year Book (1895), pp. 257-268.

Worsdell, IV. C., Principles and Practices of Pruning:-Gard. Chron., Third Series, Vol 24 (1898), No. 608, pp. 133-135. 


\section{1}


